\title{
Metal-based nanoparticles, sensors, and their multifaceted application in food packaging
}

\author{
Antul Kumar ${ }^{1}$, Anuj Choudhary ${ }^{1}$, Harmanjot Kaur ${ }^{1}$, Sahil Mehta ${ }^{2}$ (D) and Azamal Husen ${ }^{3^{*}}$ (10
}

\begin{abstract}
Due to the global rise of the human population, one of the top-most challenges for poor and developing nations is to use the food produces safely and sustainably. In this regard, the storage of surplus food (and derived products) without loss of freshness, nutrient stability, shelf life, and their parallel efficient utilization will surely boost the food production sector. One of the best technologies that have emerged within the last twenty years with applications in the packaging of food and industrial materials is the use of green mode-based synthesized nanoparticles (NPs). These NPs are stable, advantageous as well as eco-friendly. Over the several years, numerous publications have confirmed that these NPs exert antibacterial, antioxidant, and antifungal activity against a plethora of pathogens. The storage in metal-based NPs (M-NPs) does not hamper the food properties and packaging efficiency. Additionally, these M-NPs help in the improvement of properties including freshness indicators, mechanical properties, antibacterial and water vapor permeability during food packaging. As a result, the nano-technological application facilitates a simple, alternate, interactive as well as reliable technology. It even provides positive feedback to food industries and packaging markets. Taken together, the current review paper is an attempt to highlight the M-NPs for prominent applications of antimicrobial properties, nanosensors, and food packaging of food items. Additionally, some comparative reports associated with M-NPs mechanism of action, risks, toxicity, and overall future perspectives have also been made.
\end{abstract}

Keywords: Nanotechnology, Metal-based nanoparticles, Food processing, Antimicrobial properties, Low-density

\section{Introduction}

In the present century, food safety threats are emerging rapidly at an unpredictable rate [1]. Astonishingly, more than one-third of the total globally produced food gets wasted. This annual global food-as-waste value impacts the human's stomach directly as it weighs around 1.3 billion tonnes. Interestingly, this food wastage also impacts the global economy as food wastage is worth nearly $\$ 1$ trillion. This whopping number is so much big that this amount worth is equal to the upcoming USA infrastructure bill meant for future construction projects

${ }^{*}$ Correspondence: adroot92@yahoo.co.in

${ }^{3}$ Wolaita Sodo University, P.O. Box: 138, Wolaita, Ethiopia

Full list of author information is available at the end of the article throughout the entire USA. According to the FAO's Food Loss Index (FLI), approximately $14 \%$ of the total food produced gets wasted in the post-harvest stage only. Furthermore, according to UNEP Food Waste Index (FWI) report 2021, more than 900 million tonnes of food waste were produced in 2016 with a maximum share of $61 \%$ from households solely [2, 3]. Considering all these facts, the point is that substantial food stocks are not eaten by humans. This even puts enormous negative pressure on the environment, social status, and economics. Additionally, another frightening issue is the continued consumption of contaminated food products with very low nutrients value. This consumption eventually leads to various disease epidemics and threatens the food security of every nation. As a result, food-borne pathogens original author(s) and the source, provide a link to the Creative Commons licence, and indicate if changes were made. The images or other third party material in this article are included in the article's Creative Commons licence, unless indicated otherwise in a credit line to the material. If material is not included in the article's Creative Commons licence and your intended use is not permitted by statutory regulation or exceeds the permitted use, you will need to obtain permission directly from the copyright holder. To view a copy of this licence, visit http://creativecommons.org/licenses/by/4.0/. The Creative Commons Public Domain Dedication waiver (http://creativeco mmons.org/publicdomain/zero/1.0/) applies to the data made available in this article, unless otherwise stated in a credit line to the data. 
or spoilage needs intensive screening and monitoring to access the challenges in the food industries and or food safety [4-10]. Considering this, the issue of strengthening the food regulation system throughout the world was emphasized by the World Health Organization (WHO) in their slogan "farm to plate" put forward in 2015 [11].

Nanobiotechnology, the emerging field of biology has gained much attention since the twentieth century and has been established as an area with multiple applications $[12,13]$. As per history, nanotechnology has brought the revolution after the efforts of a noble laureate, Richard P. Feynman, who also gave a lecture entitled "There's plenty of room at the bottom" in the year 1959. Since then, nanotechnology has been observed to take bigger and bigger leaps that have resulted in designing as well as manufacturing of characterized particle(s) in a significantly desired shape, size, and form $[4,5,13,14]$. This can be evidentially supported by the fact that precision placement, controlled manipulation, measurement, modelling, and production of nanoparticles (NPs) in nanoscale is an easy task that has been pursued excellently on a global scale [15-18].

NPs are broadly classified into various classes based on their physical and chemical properties: Ceramics NPs, Carbon-based NPs, Semiconductor NPs, Metal NPs, Lipid-based NPs, and Polymeric NPs [18, 19]. The shape, size, facet, advanced optical properties (broad absorption band range), and excellent edge cutting (for example, coating of gold NPs) are primarily used in multiple avenues. One of the very prominent examples is the use of gold-coated NPs in the Scanning Electron Microscopic (SEM) technique for increasing the visualization efficiency for obtaining higher quality images [18-20]. Similarly, NPs have been utilized in the form of nanospheres, nanobelts, nanoplates, nanorods, nanoprisms, nanotetrapods, and nanocubes. These can be categorized into round decahedrons, face-centered cubic, star decahedron, regular decahedron, marks decahedron, cuboctahedron, and icosahedrons [21-23]. Interestingly, the use of NPs has also accelerated in applied and commercial microbiology areas due to various properties. These properties include high electrical conductivity, active surface, optical properties, specific ion release, resistance to crushing (near identical strength), stable agglomeration state, discrete energy levels, and durable stability under circulatory systems $[4,5,8,24-26]$.

As per the estimations by Institute for Health and Consumer Protection (IHPC), the NP-based market was predicted to touch the mark of $\$ 20$ billion by the year 2020 [27]. These M-NPs show much advancement over synthetic chemicals used for food packaging and their preservation over a long duration of time. The unique characteristics, different physical and chemical properties, and microbial response to each NPs result in variation in practical approach in food packaging. Further, various types of M-NPs and their specific derivatives have gained enormous attention for their promising antimicrobial properties and empowered food industries in the past two decades [26, 27]. For example, multiple M-NPs such as zinc oxide $(\mathrm{ZnO})$, magnesium oxide $(\mathrm{MgO})$ copper oxide $(\mathrm{CuO})$, silicon $(\mathrm{Si})$, titanium dioxide $\left(\mathrm{TiO}_{2}\right)$, calcium oxide $(\mathrm{CaO})$, silver oxide $\left(\mathrm{Ag}_{2} \mathrm{O}\right)$, and gold $(\mathrm{Au})$ have been already investigated for exhibiting the antimicrobial activity, and they also minimize biofouling [8, 19, 26-28].

Specifically, in terms of microbiological food perspective, nanotechnology has been effective in increasing food safety because of its significant role in every stage of the food chain ranging from food packaging, processing, preservation, quality monitoring to storage $[8,13]$. Moreover, the use of NPs in nano-packaging components has been shown to improve long-distance packaging, storage product stability, and prevent deterioration from food spoilage $[14,15,28]$. Nano-components also have shown antimicrobial properties and restricted the growth activities of both pathogenic and spoilage microbes [12, 13, 22, 29] and hence, act as an emerging tool in food processing and preservation industries [29-31]. Due to nanomaterial and nanosensor-based assays, the easy identification of foodborne bacterial species including Listeria monocytogenes, Escherichia coli, and Salmonella spp. have also been reported [9-11].

NPs-food packaging materials are commonly made from polyethylene terephthalate (PET), polypropylene $(\mathrm{PP})$, and non-degradable polyethylene (PE), where molecules penetration of $\mathrm{H}_{2} \mathrm{O}$ and $\mathrm{O}_{2}$ and is prevented. Additional, coatings containing flavors, antioxidants, antimicrobial agents, emitting sachets, and preservatives with the aim to safety and maintain food quality. It also offers antimicrobial active packaging, upgrading food stability, color, detection of food spoilage organism, the possibility of oxidation prevention, UV protection activity, and bio-based packaging [34]. For example, Silver-NPs (AgNPs) have increased antibacterial properties, SilicaNPs (SiNPs) in the plastic restrict the gaseous exchange that enhances the product's shelf life, Nano-sized iron particles have increased reactivity and bioavailability. The incorporation of MNPs has significantly enhanced the shelf life of canned or preserved food with efficient management of spoilage. This has resolved the crises of food spoilage and ensuring food reaches to masses [35].

Furthermore, NPs have been used to improve the food quality and act as antibacterial agents including fullerenes, carbon nanotubes (CNTs), nano- $\mathrm{ZnO}$, nano$\mathrm{Ce}_{2} \mathrm{O}_{4}$, nano- $\mathrm{TiO}_{2}$, and nano-Ag that display antimicrobial characteristics [4]. In this regard, the extensive usage 
of nanosilver (nano-Ag) like NPs is evaluated as highly efficient control over various drug infectious or resistant microbes and confirms to be good in preventing organism evolving antibiotic resistance [5, 6, 10, 15]. For example, nano-Ag that was synthesized by a common "green" synthesis technique using leaf extract of Plectranthus amboinicus has been effective activity against the Penicillium spp. and E. coli $[6,7,31]$. Thus, based on the current information, the present review unfolds the sustainable green synthesis of NPs for prominent applications of antimicrobial properties, nanosensors, and food packaging of food items. An attempt has also been made to understand the M-NPs mechanism of action, risks, toxicity, and future perspectives.

\section{Green synthesis of NPs-An emerging and more sustainable approach toward mitigating the food packaging challenges}

Several physical and chemical methods have been developed for the NPs fabrication and or synthesis. However, the deliberate synthesis of NPs by chemical/physical methods requires a fairly large amount of toxic chemicals which also leave undesirable materials that pollute the environment [28]. Therefore, in recent years, biogenic or green synthesis of NPS using fungi, bacteria, actinomycetes, algae, and higher plants have emerged as potential nanofactories which are also cost-effective and eco-friendly [36-38]. Additionally, it has been noticed that the NPs prepared using plant extracts are more stable, cheap, mono-dispersed, and takes less time to reduce $[27,28,39]$. Thus far, several reviews have been published on the fabrication and characterization of NPs $[36,38$, $40-43]$.

It has been observed that several factors such as the concentration, $\mathrm{pH}$, incubation time, and temperature of plant extract or biomass affect the conversion of metal ions to NPs and control the shape and size of NPs during fabrication. In a study, NPs biosynthesized from leaf extract of Carica papaya where $\mathrm{CuO}$ was used as a catalyst. It was showing the degradation of blue dye R-250 (Coomassie brilliant) under exposure to sunlight. The reduction in absorption intensity of dye enriched with $\mathrm{CuO}-\mathrm{NPs}$ has been achieved without any fluctuation in actual absorption at $559 \mathrm{~nm}$ in the visible spectrum region after $2 \mathrm{~h}$. Such degradation of dye has been dependent on the morphology and $\mathrm{CuO}-\mathrm{NPs}$ size [27].

In another finding, $\mathrm{CuO}-\mathrm{NPs}$ were derived from aqueous leaf extract of Diospyros montana and $\mathrm{CuSO}_{4}$. The plant-based extract has advantages over conventional or chemical methods. It does not need sterile conditions and cell culture maintenance. It also acts as a natural capping agent, helps in the stabilization of NPs along with the reduction of NPs-synthesis to a single step. The stabilization and reduction of such large-scale NPs production are achieved by the combined activity of various biomolecules such as flavonoids, terpenoids, phenolic acid, alkaloids, tannins, polysaccharides, enzymes, amino acids, and proteins [26, 40-42].

The derived $\mathrm{CuO}$-NPs from leaf extract of $D$. montana was exhibited antibacterial activities against $P$. aeruginosa, P. vulgaris, K. pneumoniae, E. coli, C. xerosis, $S$. epidermidis, S. viridans, S. pyogenes, S. mutans, and $S$. aurens. The green synthesis of NPs has shown effective and efficient photocatalytic degradation of various dyes. It can be operated as a catalyst in the reduction of toxic materials, dyes, and industrial waste. Except for these, such NPs fabrication is inexpensive and easily available without selecting any organic solvent [26].

In another published article, high concentration anisotropic suspensions of AgNPs by soluble protein was hydrolysate or peptone using low volume but high amount nano synthesis and thus, increases the economic importance of green route-based synthesis. Numerous reports have been evidenced of the presence of multidrug-resistant bacterial types due to mutation, changing environmental conditions, and pollution. To overcome these issues, rapid upsurge in green route NPs is extremely needed, and such fabrications help to combats the microbial strain infections. [45].

Moreover, it offers the synthesis of specific microbial nutrients like peptone-coated AgNPs that proved to be economically and ecologically feasible nano-synthesis. The facile and rapid synthesis of peptone-coated AgNPs with desired parameters might give various advanced methods in the characterization of antimicrobial application. Bastos-Arreta et al. [40] used the grape stalk waste extract and suggested that they possessed components that can act as a stabilizer and reducing agent in NPs production. The AgNPs synthesized from leaf extract of Eriobotrya japonica were used in the catalytic degradation of reactive dyes. Several other plants and their extract has been used for AgNPs fabrication, such as Areca catechu [44], Erigeron bonariensis [45], Momordica charantia [46], Euphorbia amygdaloides [47], Impatiens balsamina [48], Aloe vera [49], Artemisia absinthium [50], Chelidonium majus [51], Terminalia chebula [52], Cerasus serrulata [53], Solanum indicum [54], Fraxinus excelsior [55] and so on. Quite often, the fabricated NPs have shown antimicrobial response [25].

Green route synthesis offers the great intrinsic capacity to oxidize, reductions of dyes, stabilization, highly negative zeta potential of synthesized MNPs, and biodegradability. Green synthesis of the M-NPs provides promising advantages with the least disadvantages reported so far [56-59] Likewise, the formation of M-NPs achieved through leaf extracts contains multiple involvements of 
primary and secondary metabolites. Therefore, it is very tough to evaluate the function of single metabolites at par. Furthermore, the synthesis requires multiple steps and may pass through several complementary chemicals to know the exact role of single metabolites [60,61], thus some extensive investigations are required.

\section{Derivatives, properties, and mode of action}

In the past two decades, metal oxides (MOs) and mixed metal oxides (MMOs) are the most studied material and explored recently in the field of food packaging. MOs display defects or extent of vacancies that distinguish the nature of MOs from each other. It also affects the oxygen partial pressure above MOs and causes a continuous alteration in equilibrium composition and lattice parameters. The d-block MOs $\left(\mathrm{CuO}, \mathrm{MgO}, \mathrm{ZnO}\right.$, and $\left.\mathrm{TiO}_{2}\right)$ have antimicrobial activities due to their minute variations in the O-atom defects and stoichiometry [62]. MO-NPs integration on polymers (bio-based or petroleum-based) alleviates superiority in the properties of the nanocomposites [63]. Several structural-based NPs and nanoscale MOs are utilized to modify the mechanical properties, thermal stability, and barriers in food packing.

However, $\mathrm{Ag}$ and $\mathrm{Au}$ are the most reliable metal and are extensively used due to their lack of reactivity. On the other hand, the oxides of Au and Ag are not getting much importance because of instability in nature [64]. For instance, $\mathrm{Au}_{2} \mathrm{O}_{3}$ has the heat of formation is $119.3 \mathrm{~kJ} / \mathrm{mol}$ and implying its instability [65]. Oxidative stress and free metal ion toxicity are the well-known proposed mechanisms for antimicrobial activities [66]. Both of them (AgNPs and Au-NPs) have high photothermal activity, ease of detection, polyvalent effects, and high functionalization activity. It leads to their non-toxicity and antibacterial activity. These NPs bind to the bacterial membrane and induce the alteration of membrane potential. Hence, they reduce the ATP level and inhibit tRNA binding to the ribosome [67]. Au-NPs show a greater antibacterial response for the gram-positive bacteria than the gramnegative bacteria because of facile internalization in gram-negative bacteria [68].The Au-NPs biocidal properties are due to the dispersion extent in the medium and roughness. The potential functionalization of Au-NPs tagged them as "ideal NPs" for antimicrobial activities.

In contrast to $\mathrm{Au}-\mathrm{NPs}$, the Ag-NPs incorporation into the polymer matrix alters the antibacterial activity and gas permeability. The derivatives of Ag-NPs such as silver-embedded cellulose nanofibrils have a $10.72 \pm 4.96 \mathrm{~nm}$ average size and peak for surface plasmon resonance absorption at $397 \mathrm{~nm}$ [69]. The Ag ions can also be released from its composite films and showing antimicrobial activity against Listeria monocytogenes and E. coli.
Most importantly, the $\mathrm{Cu}-\mathrm{NPs}$ and $\mathrm{CuO}-\mathrm{NPs}$ are the two main effective agents used in food packaging materials. $\mathrm{CuO}-\mathrm{NPs}$ are more prominently exploited for reducing the fungal, bacterial, and viral growth in food packing [70]. The higher surface area of $\mathrm{CuO}-\mathrm{NPs}$ has increased interaction with the cellular membrane. The $\mathrm{CuO}-\mathrm{NPs}$ have shown antibacterial activity against both gram-positive and gram-negative bacteria in all biopackaging systems. The bio-packaging systems involve copper incorporated chitosan, cellulose, agar, and poly (3-hydroxybutyrate- co-3-hydroxyvalerate) [71-74]. However, some polymeric systems $(\mathrm{CuO}$ and chitosan nanofibers) have been observed to show synergistic effects [72]. It is well known that the size, surface area, structure, morphology, and variation in oxidation states confer antimicrobial activity of MOs including $\mathrm{CuO}$. The coupling or doping of $\mathrm{CuO}$ with other metals or MOs can also potentiate the overall properties of packaging material.

Interestingly, the $\mathrm{TiO}_{2}$-NPs are highly thermo-stable materials with modified properties in biodegradable films. $\mathrm{TiO}_{2}$-NPs in the food grades are photostable, cheap, non-toxic, and have antimicrobial activity. The controlled size and colloidal suspension can be attained with help of wet chemistry methods [75]. The polymer incorporated $\mathrm{TiO}_{2}-\mathrm{NPs}$ have several properties such as photocatalytic activity, mechanical, physical, and thermal properties along with anti-bacterial properties. The used polymers are chitosan, polylactic acid, high-density polyethylene, and starch. The photocatalytic activities are based on the adsorption of the N(III) atom of the imidazole ring on the $\mathrm{Ti}(\mathrm{V})$ atom, therefore, high and stable energy adsorption takes place. Thus, $\mathrm{TiO}_{2}$ induces the photocatalytic degradation of ornidazole and confers the catalytic degradation at a microscopic level [76].

Furthermore, $\mathrm{ZnO}$ is another novel material at the nano-sized level which is considered as a safe antimicrobial material for next generations food preservatives. US Food and Drug Administration has been listed $\mathrm{ZnOs}$ as a food additive and approved as a generally recognized as safe material [77]. ZnO-NPs are potent materials because of their antimicrobial and photocatalytic activities. The photocatalytic activity is based on morphology and can be altered from spherical one to hexagonal nanodisks or nanorods [78]. ZnO-NPs have improved properties concerning crystalline structure, chemical composition, morphology, surface functional chemical group, and specific surface area.

Apart from the above-mentioned $\mathrm{MOs}, \mathrm{MgO}$ is another oxide that has high thermal conductivity and low electrical conductivity. It even has high stability that confers strong antimicrobial properties. Apart from this, it displays impermeability to gas, flexibility, thermal 
stability, recyclability, and hence, MgO-NPs based packaging material has substituted the several construction materials of food packaging [76].

Similarly, the Mg-NPs incorporated in biodegradable polymers has improved properties (such as mechanical, optical, barrier, and thermal) besides antimicrobial activity. For instance, the polylactic acid-MgO-NP nanocomposite films have improved $22 \%$ tensile strength and $46 \%$ plasticity using $2 \% \mathrm{MgO}$. Additionally, the water vapor and oxygen barrier properties are also improved by $57 \%$ and $65 \%$, respectively $[79,80]$.

Numerous NPs like $\mathrm{TiO}_{2}$ and $\mathrm{ZnO}$ are frequently utilized as photocatalyst agents to degrade microorganisms and organic molecules whereas layered silicates, nano-clays, and Ag-NPs can be toxic to food spoilage pathogens $[81,82]$. The photocatalytic activities of nano$\mathrm{TiO}_{2}$ and nano-ZnO are contributed to $\mathrm{ROS}$ generation and lead to cytoplasmic oxidation of microbial cells terminated with cell death. Ag-NPs can attach to the cell surface and deteriorate the lipo-polysaccharides, thus, forming a membranous pit on the cell wall [82]. It has also been suggested that Ag-NPs produce ROS and free radicals which cause apoptosis leading to cell death, thus checking their replication [25]. The Ag-NPs plastic polymer complex such as zeolite having low density compounds can enhance shelf life and inhibits microbial growth in orange juice. However, such an active nanocomposite complex has been proved as a good antimicrobial agent with high temperatures. ZnO-NPs show diverse inhibition against Salmonella aureus, E. coli and Bacillus atrophaeus and are even much attractive for packaging. Under high UV conditions, $\mathrm{ZnO}$ can liberate a higher amount of hydrogen peroxide that causes oxidative stress in microbes [82].

To evaluate the decay rate, various indices are marked such as pyrogallol peroxidase (POD), ethylene, malondialdehyde (MDA), and polyphenol oxidase (PPO). Under $\mathrm{UV}$ radiation, $\mathrm{ZnO}$ can oxidize ethylene into carbon dioxide and water and decreases the accumulation of POD, ethylene, MDA, and PPO that enhance the shelf life of food products [83]. Conclusively, $\mathrm{ZnO}$ is comparatively more attractive and efficient than Ag-NPs due to its cost-effectiveness and low toxicity. European Food Safety Authority approved food contact like nano-TiN is derived via the heating of $\mathrm{TiO}_{2}$ in nitrogen gas at high temperature and is chiefly used as a packaging agent $[83,85]$.

\section{Efficacy of metal based-nanoparticles (M-NPs) as sensors}

In the food packing industry, nanotechnology provides promising solutions for increasing the shelf-life period, safety from microbes, and quality assurance [33]. The M-NPs have metal as a precursor molecule that is produced by either chemical, physical or biological methods. While the fabrication of M-NPs, various nano-based inorganic materials are employed including gold $(\mathrm{Au})$, silver $(\mathrm{Ag})$, zinc $(\mathrm{Zn})$, titanium oxide $\left(\mathrm{TiO}_{2}\right)$, silicon oxide $\left(\mathrm{SiO}_{2}\right)$, magnesium oxide $(\mathrm{MgO})$, and zinc oxide $(\mathrm{ZnO})$ (Fig. 1). They can either make direct contact or migrate slowly to react with food organic materials $[29,30]$.

Metals such as $\mathrm{Ag}$ and $\mathrm{Au}$ are considered excellent materials because they have high plasmon resonance [31, 31, 32, 86]. The M-NPs have a higher surface area and thus brought higher activity to the surface plasmons. Therefore, this property of the plasmon resonance phenomenon is being used for employing it as a sensor for identifying the diverse molecules present in the environment [87]. Moreover, advancement in nanotechnology helps in the transport of nano-metallic compounds effectively in food products [87] and ensures their quality via inhibiting the growth of food spoilage agents (Table 1).

\section{Au-NPs}

The Au-NPs are simply bioconjugated to DNA, aptamers, antibodies and therefore, used for bio-detection. Furthermore, the electromagnetic and unique optical properties allow them to enhance the sensitivity of the sensor [88]. For instance, melamine is an adulterant used in the milk to increase the nitrogen content and gives false readings for the total protein content in the milk. The gas chromatography-mass spectroscopy (GC-MS) is a standardized procedure for the detection of melamine recommended by the US Food and Drug Administration. However, in comparison, the Au-NPs are simple, highly sensitive, and cheap options for quantifying melamine as they have a quantification limit of $0.05 \mathrm{mg} / \mathrm{L}$ that exceeds the limit of $0.05-10 \mathrm{mg} / \mathrm{kg}$ for the GC-MS method (Table 1). The red color of Au-NPs colloidal solution is imparted under the absorbance of $523 \mathrm{~nm}$ that confirms the proper $\mathrm{Au}$ NPs dispersion $[89,90]$. The presence of melamine in the milk induces conjugation with Au-NPs and imparting blue color at a $640 \mathrm{~nm}$ absorbance value [90]. The chemical resonance energy transfer is considered to be responsible for high sensitivity for melamine detection.

Another example of milk adulteration is the addition of detergent $(1.2 \mathrm{~g} / \mathrm{L}$ in water). Methylene blue and azure A are the organic dyes that are used for detecting detergent supplementation in milk. Because of the thousand times higher value of extinction coefficient, Au-NPs are also employed for detecting the anionic component of detergents in milk [90]. Apart from non-biological adulteration, the NPs have been reported to be identifying various food pathogens. For example, milk is rich in nutrients and highly prone to pathogenic attacks. The $\mathrm{Au}-\mathrm{NPs}$ combined with propidium monoazide-asymmetric polymerase chain reaction (PCR) is used to detect 


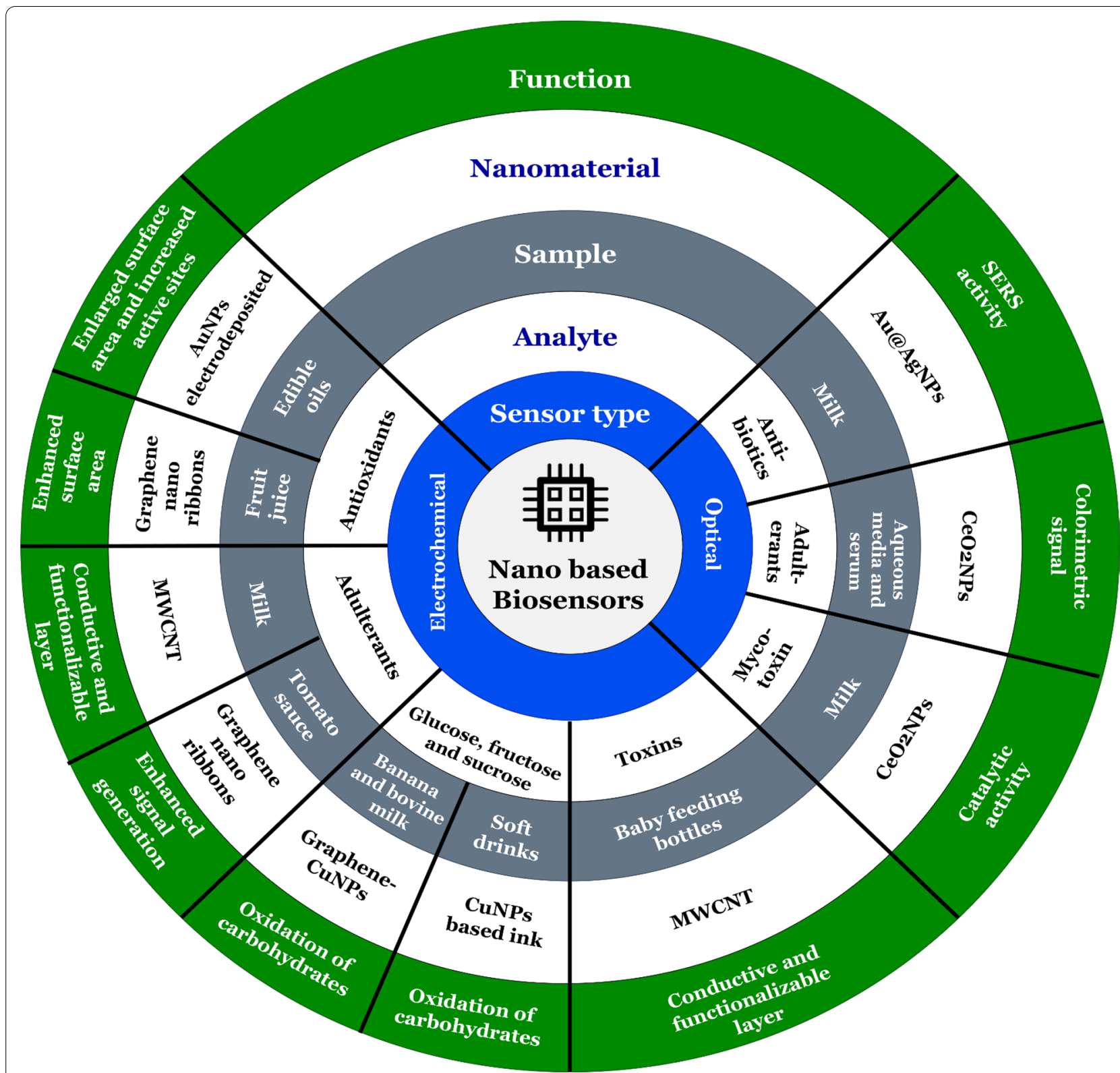

Fig. 1 Overview on different types of nanosensors and their functional role in the preservation of food products

the emetic Bacillus cereus in the milk. Au-NPs conjugated with the long genomic DNA fragments (amplified by PCR) are stabilized by adding $\mathrm{NaCl}$. After few minutes the visual detection is possible or with the help of a UV spectrophotometer $[89,91]$. Similarly, Salmonella is detected in the milk with the help of isothermal recombinase polymerase amplification and unmodified Au-NPs combination (Table 1). This method is rapid, accurate, and cost-effective as compared to other standardized methods [92, 93].
Furthermore, Au-NPs have been applied for detecting meat spoilage. The tyramine, histamine, cadaverine, and phenylalanine are the biogenic amines produced by the bacterially mediated amino acid decarboxylation. The false smell is remained cryptic due to their preservation at $5{ }^{\circ} \mathrm{C}$. In a report, Au-NPs were used to measure the histidine and histamine in the chicken meat at detection limits $0.6 \mu \mathrm{M}$ and $6.59 \times 10^{-4}$ [90]. Recently, the metal nanosensors were commercially exploited and gain much attention in food preservation summarized in Table 2. 


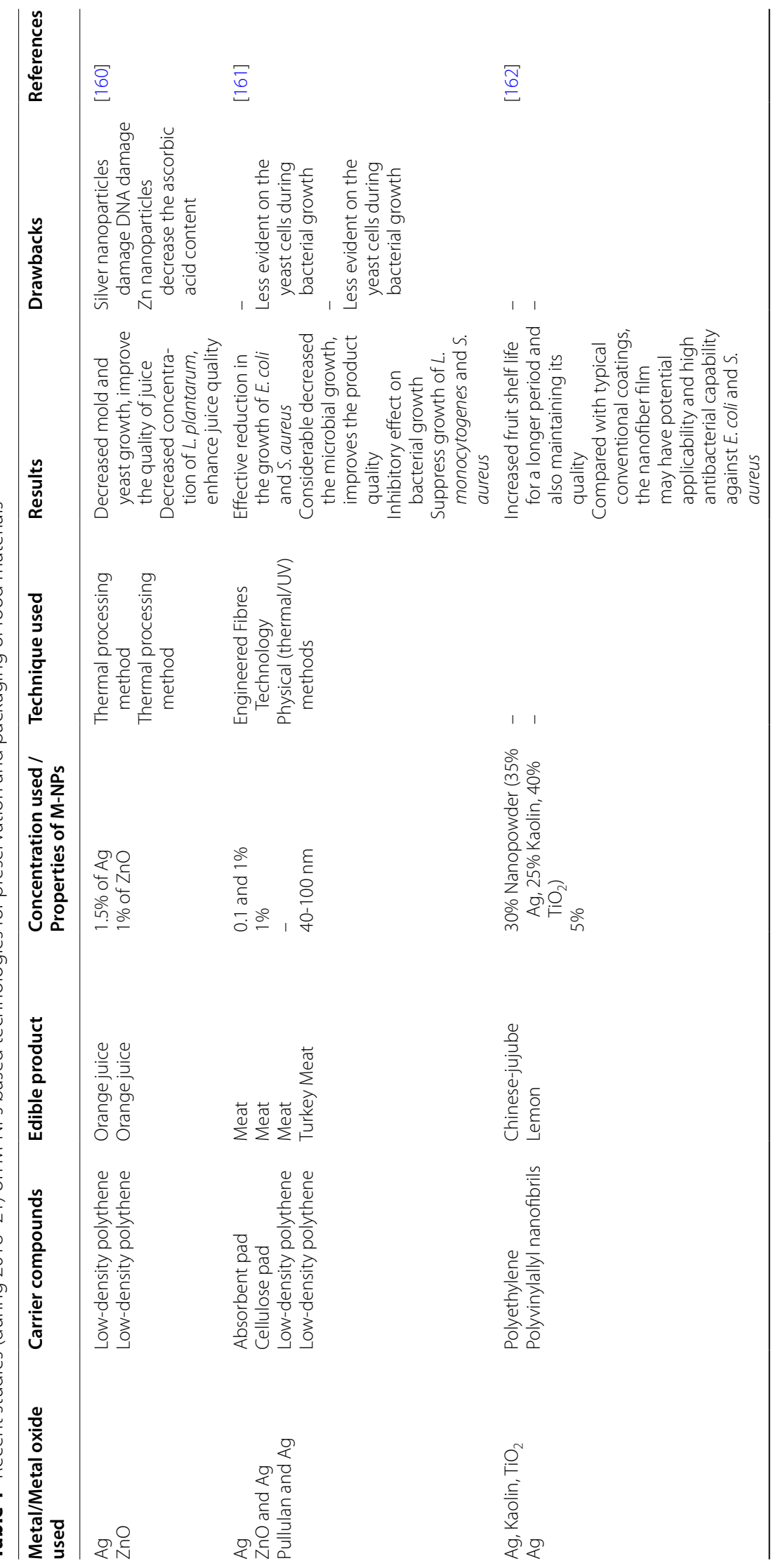


Kumar et al. J Nanobiotechnol ～(2021) 19:256

Page 8 of 25

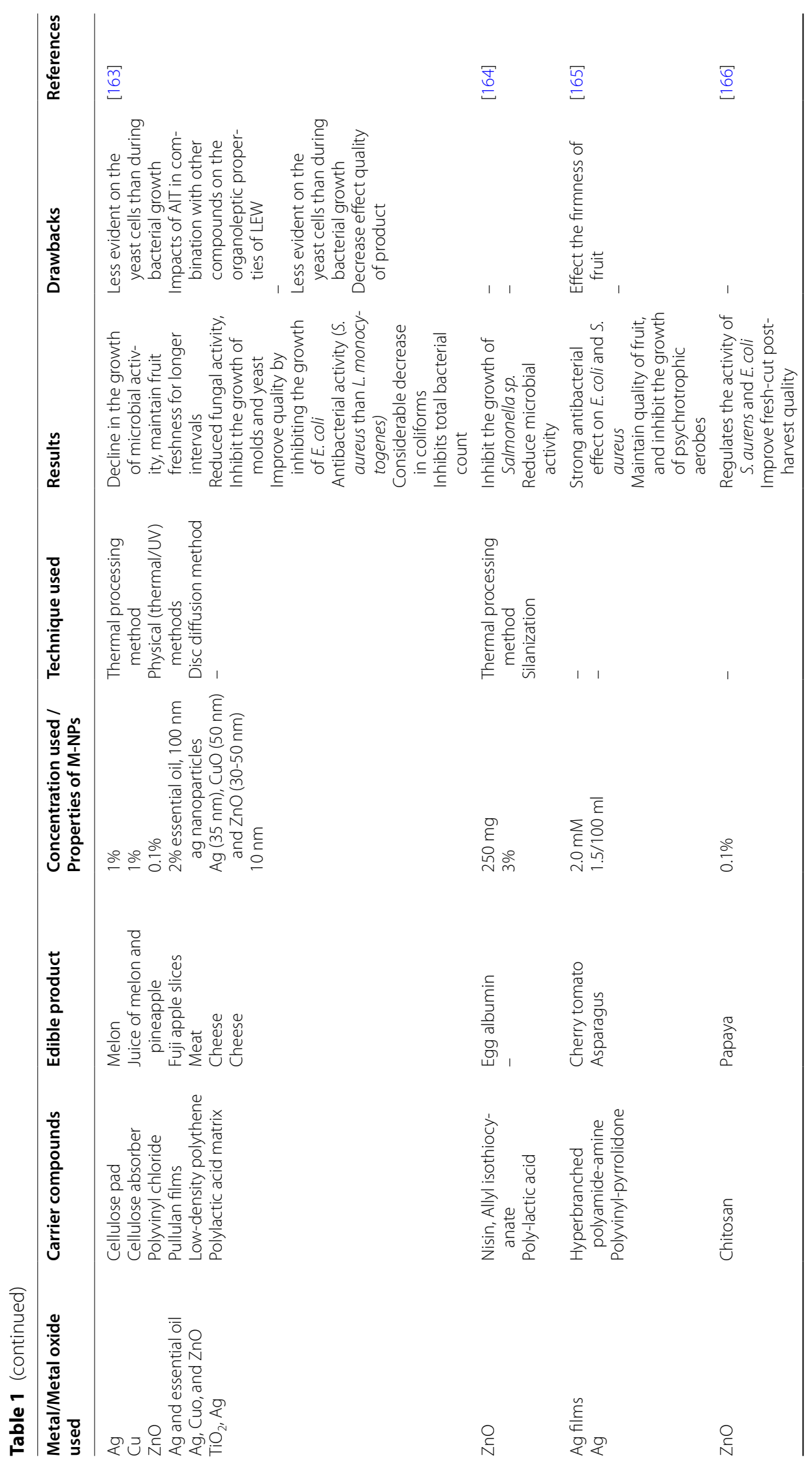




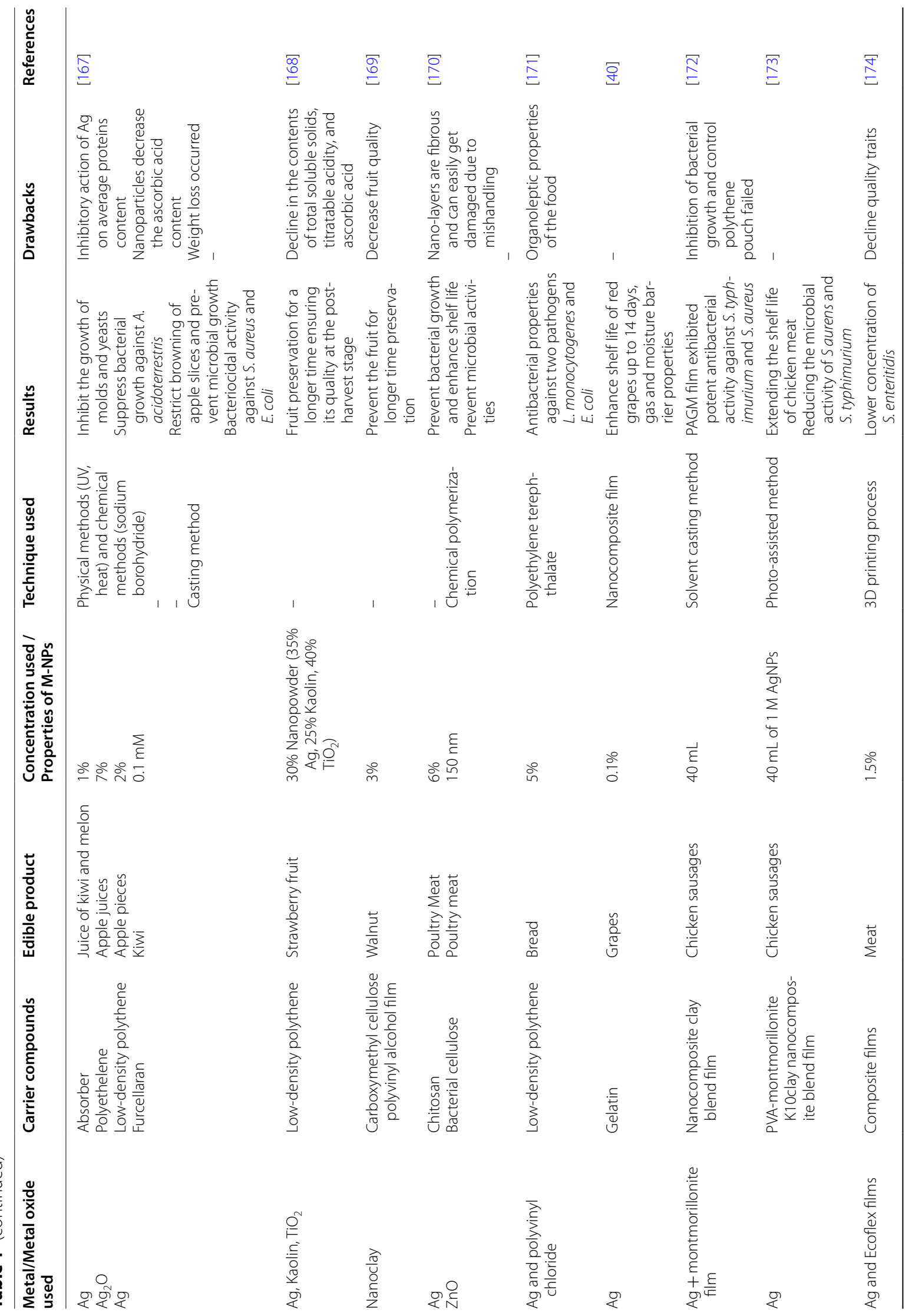




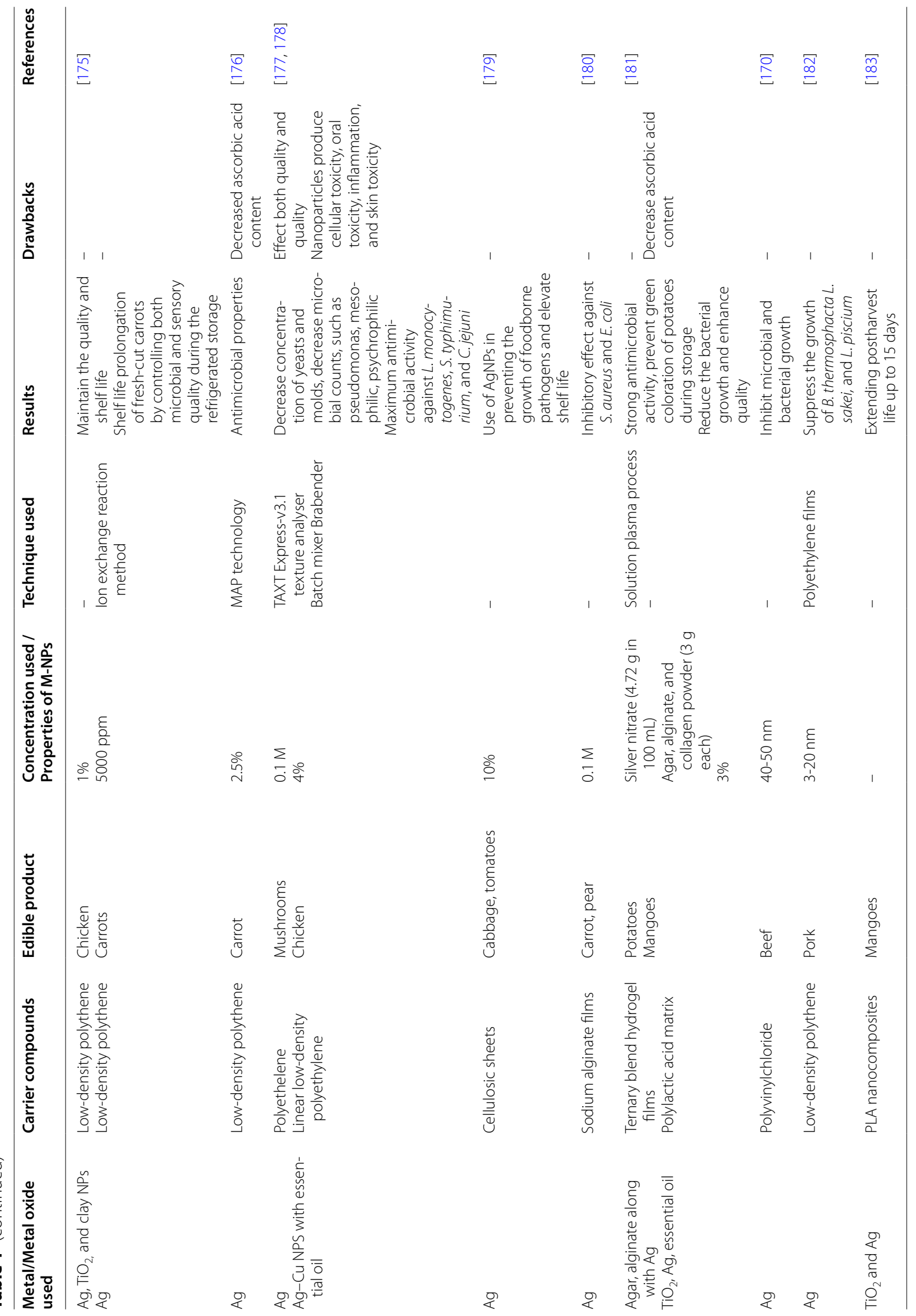


Table 2 Recent advancements (during 2018-21) in metallic sensors tested to ensure the quality of food products

\begin{tabular}{|c|c|c|c|}
\hline Edible product & Testing period (days) & Sensor used & References \\
\hline \multirow{2}{*}{$\begin{array}{l}\text { Wheat Bread } \\
\text { Red-Grapes }\end{array}$} & 15 & Polyvinylchloride, Ag-NPs & \multirow[t]{2}{*}{ [40] } \\
\hline & 25 & Polyvinyl-chloride, Ag-NPs & \\
\hline \multirow[t]{2}{*}{ Turkey Meat } & 21 & Pullulan films, Essential oils, Ag-NPs & \multirow[t]{2}{*}{ [161] } \\
\hline & 12 & Coated films with Ag-NPs & \\
\hline Kiwi & 8 & Furcellaran gelatine films, Ag-NPs & [167] \\
\hline Beef & 14 & Ag-NPs, Noncellulose polyvinyl alkyl films & [163] \\
\hline Tomato & 9 & Ag-NPs, polyamide-amine films & [172] \\
\hline Pork & 15 & Polyethylene films along with liposomes-essential oil-Ag -NPs & [182] \\
\hline Meat & 4 & Polyvinylallyl, Ag-NPs, montmorillonite films & [162] \\
\hline Meat & 28 & Ecoflex, Silica carbon Ag-NPs & [174] \\
\hline Litchi & 7 & Ag-NPs films & [184] \\
\hline Chicken & 5 & Polyethylene with $\mathrm{Ag}, \mathrm{Clay}, \mathrm{TiO}_{2}$ & [179] \\
\hline Mushroom & 21 & Polyethylene with Ag-NPs & [177] \\
\hline Carrot & 10 & Ag-NPs with low-density polyethylene & [176] \\
\hline Chicken & 21 & Ag-NPs with low-density polyethylene & [178] \\
\hline Lemon, Strawberry & 10 & Polyvinylallyl nanofibres, Ag-NPs & [162] \\
\hline Tomato, Cabbage & 7 & Cellulosic sheet incorporated with Ag-NPs & [179] \\
\hline Pear, Carrot & 10 & Ag-NPs along with $\mathrm{Na}$-alginate films & [180] \\
\hline Potato & 10 & Ag-NPs incorporated with agar or alginate & [181] \\
\hline Poultry Meat & 9 & Ag-NPs along with polyvinyl allyl films & [185] \\
\hline Saffron & 180 & Polyethylene films with Ag-NPs & [41] \\
\hline Pistachio & 8 & Low density polyethylene with Ag-NPs & {$[186,187]$} \\
\hline Olive oil & - & Polyvinyl alcohol chitosan film with $\mathrm{TiO}_{2}$ & [188] \\
\hline Almonds, walnuts & 365 & Polyethylene Ag-NPs film & [169] \\
\hline
\end{tabular}

\section{Ag-NPs}

In spite of the chemical stability, the Ag-NPs are a better choice than the Au-NPs. It is because of sharper extinction bands, higher extinction coefficients, higher scattering to extinction ratio, and also higher field enhancement. However, recent developments have been made to enhance chemical stability by focusing on optical properties [94]. The stable colloidal synthesis of Ag-NPs is mediated with the help of optimized $\mathrm{AgNO}_{3}$ and $\mathrm{NaBH}_{3}$ concentrations in a factorial design. The interaction between Ag-NPs and the amine group is strong and enhances the sensitivity of melamine detection. The detection of melamine is noted as yellow to red color change as surface plasmon bands fall at a longer wavelength. Since there are no stabilizing agents; hence, the detection limit is $0.009 \mathrm{mg} / \mathrm{L}$ [89].

The Ag-NPs can also be used in food spoilage detection. For example, in one of the published article, the cysteine and histidine incorporated Ag-NPs were applied to detect the lactic acid in the fresh milk with no color change. The imidazole group of histidine and thiol group of cysteine bonded Ag-NPs to lactic acid and resulted in NPs aggregation along with detected color change [95].
Ag-NPs based detection is very efficient in the assessment of post-harvest spoilage of agricultural and horticultural crops. For instance, the Bacillus subtilis causes spoilage in the Musa acuminata and produces 1,2-Benzenedicarboxylic acid, bis (2-methyl propyl) ester (a volatile compound) during its spoilage. The colloidal solution Ag-NPs is when applied to such spoiled bananas turned into reddish-brown color. Similarly, this method is also applicable to other fruit crops (Table 2) [96]. For instance, the spoilage of onion in the post-harvest period can be detected based on the release of organosulfur compounds. The application of Ag-NPs changes its color from yellow to orange initially and followed by an increase in spoilage it becomes colorless. The sensitivity and specificity of the sensor have been confirmed by the calorimetric analysis and UV visible spectroscopy for volatile sulfur compounds [97].

\section{ZnO-NPs}

Devi et al. [98] had developed a chitosan-modified $\mathrm{ZnO}$ NP-based sensor with xanthine content. The xanthine oxidase bounded on the carbon nanotube multilayer system associated with $\mathrm{ZnO}$. The detection limit was observed to be $0.01 \mathrm{mM}$. Further, in the chicken thigh, 
$\mathrm{ZnO}$ is used to restrict microbial growth and regulates $\mathrm{pH}$ value [110]. However, $\mathrm{Ag}-\mathrm{ZnO}(0.25 \%$ and $1 \%)$ helps to detect the growth of Lactobacillus plantarum in orange juice and causes significant Salmonella inactivation, mold counts, and decreases permeability using polylactic acid $[99,106]$. The antimicrobial activity is elevated by exposure to visible light and it with decreasing NPs size [151].

\section{Other metal NPs}

Apart from the Ag, Au and Zn-based NPs, the next most important NPs are of $\mathrm{TiO}_{2}$-NPs which have been also employed in detecting the pathogen contamination. $\mathrm{TiO}_{2}$-NPs immobilized Salmonella in the buffer solution and absorb UV light. The absorption is inversely proportional to the concentration of Salmonella bacteria which is showing high sensitivity and act upon a very low concentration of bacteria population [99]. $\mathrm{A} \mathrm{TiO}_{2}$ and graphene composite has been developed to check the freshness of meat. It also evaluates the oxidation activity of xanthine oxidase $[98,100]$. Except these, $\mathrm{TiO}_{2}-\mathrm{NPs}$ can be used to detect the pathogenic bacteria produced in the milk. The antibodies coupled with NPs are used to capture the Salmonella bacteria present in the milk. The external magnetic field has been applied to separate bacteria from analyzing samples.

Similarly, $\mathrm{ZnO}-\mathrm{SnO}_{2}$ nanocomposite has been developed to check the shelf-life of fish and meat in preserved form. The sensor shows high sensitivity to the xanthine (purine decomposed product) [101, 102]. No doubt, $\mathrm{Au}-\mathrm{NPs}$, and Ag-NPs are highly exploited in the area of metal-based nanosensors. Besides these, several studies have been given to show the role of other sensors in food security. For example, a dendritic PtNPs-based sensor is developed to detect the bisphenol A (BPA) presence [103]. BPA is leached from the inner protective resin coatings of canned foods, polycarbonate tableware, water bottles, baby bottles, and food storage containers. Thus, it accesses the quality of food and migration of BPA from the packing.

\section{Functional M-NPs in food packaging}

Several products are available on the markets to preserve food such as (i) nanoencapsulation of canola oil for fortified phytosterols (ii) Fortified fruit juice manufactured by High vive company for the encapsulation of fortified theanine, lycopene, and vitamin (iii) Life vitamins supplements used for nanoencapsulation of fortified vitamin beverages (iv) Daily boost used for encapsulation of bioactive components beverages (v) Nanoceuticals Slim Shake Chocolate, Apocarotenal, Paprika nanoemulsions or Beta-carotenal is used for the nanoencapsulation that help to enhance the flavor of the shake [104].
The employing of M-NPs in food packaging can suppress the activities of several microorganisms including Alicyclobacillus acidoterrestris, Staphylococcus aureus, Escherichia coli, Lactobacillus plantarum, and yeasts [105-108]. The M-NPs based nano-food packaging formulations include mass/heat transfer, nanobiotechnology, molecular synthesis, and nanoscale reaction engineering. These polymeric nanocomposites can be used in nano-food packaging and help them from packaging barriers like moisture, carbon dioxide, oxygen, ethanol, and improving emission of and flavors [105]. Several other advantages of M-NPs nano packaging are intelligent packaging, degradable biopolymers, and active packaging (Fig. 2) [44, 109-113].

\section{Role of metals and their forms in food packaging Au-NPs}

$\mathrm{Au}-\mathrm{NPs}$ have shown their potential as antimicrobial agents and are used in the packaging of food products. Such packaging allows regulating microbial proliferation, oxygen control via enhancing the shelf life of packed material. The M-NPs along with PLA compound (polylactic acid biopolymer) and cinnamon oil increased mechanical strength, barriers, and the natural constitution of PLA.

The antimicrobial activities against Listeria monocytogenes, Campylobacter jejuni, and Salmonella typhimurium inoculated in meat samples were identified. The Ag-CuNPs films exhibited antimicrobial activities against the bacteria. In another study, the Ag-NPs were incorporated with hydroxypropylmethylcellulose/ tragacanth/ Beeswax against the activity of gram-negative (Klebsiella pneumoniae ATCC-10031, S. typhimorum ATCC-14028, E. coli ATCC-8739, and Pseudomonas aeruginosa ATCC9027,) and gram-positive (L. monocytogenes ATCC-7644 Streptococcus pneumoniae ATCC-49615, Bacillus cereus ATCC-1247, and S. aureus ATCC-25923) and confirmed the dose-dependent inhibitory effect for both gram-negative and gram-positive bacteria [114]. However, prepared nanocomposites of Laponite/Ag-NPs/Carrageenan were encapsulated with the film of polypropylene-oxygen plasma surface also displayed the same behavior.

Moreover, Ag-NPs were prepared from the extract of Digitalis purpurea that assessed mechanical barrier, adhesion, and antimicrobial properties of nanocomposites. It remarkably enhanced the susceptibility of $S$. aureus and E. coli toward these nanocomposites [115]. Similarly, Kim et al. [116] reported that Ag-NPs were synthesized biologically derived from Nigella sativa extract prepared with chitosan-based nanocomposite films. Such nanocomposite films were developed $\mathrm{pH}$-dependent persistent Ag-NPs release and assessed the efficacy of films against two gram negative bacteria $(P$. aeruginosa and 


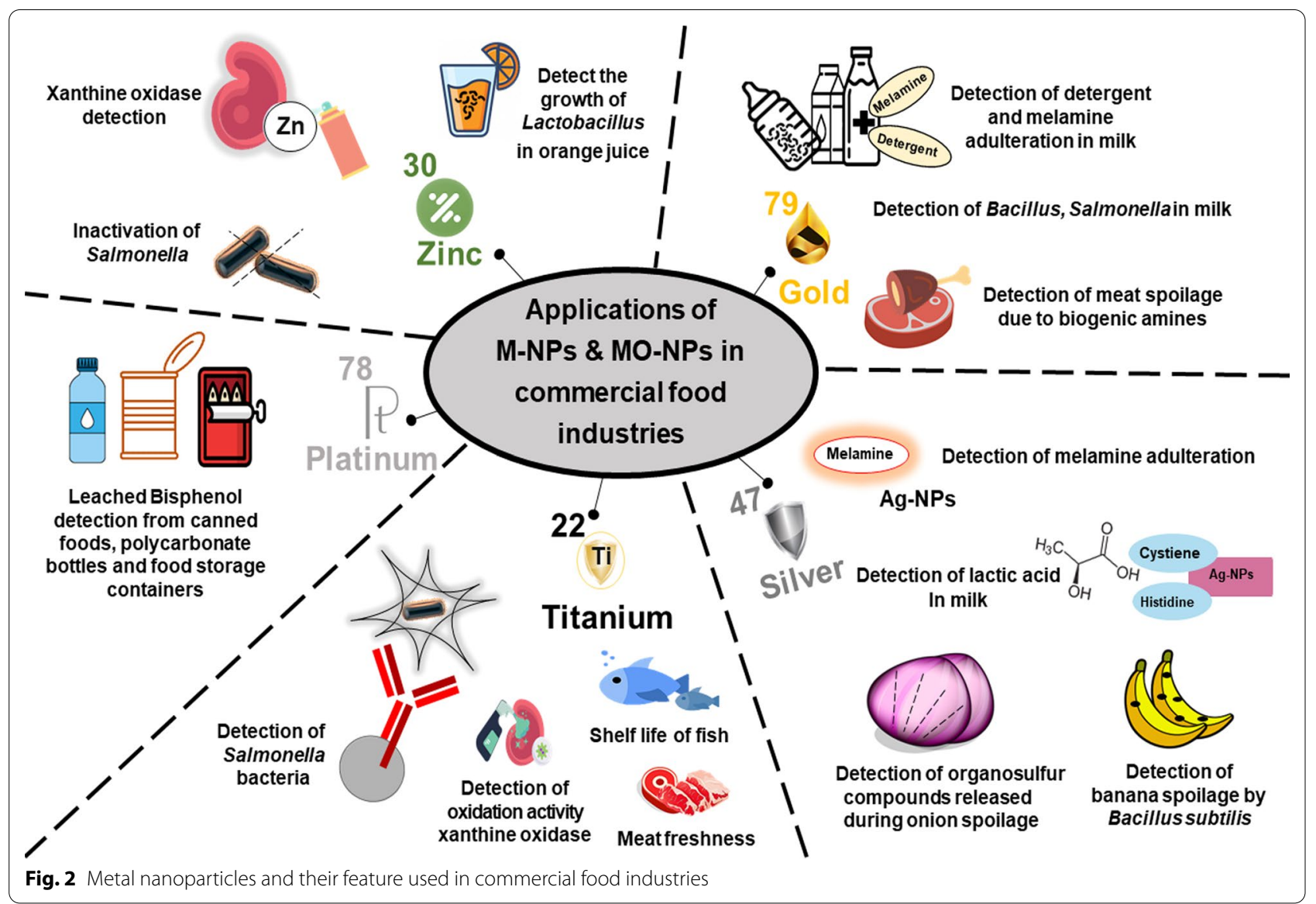

E. coli) and two gram positive bacteria (S. aureus and B. subtilis). Thus, indicated notable antibacterial properties depend upon the concentration of Ag-NPs that retards bacterial growth (Table 3).

Recently, the Ag-NP layer of the chitosan-based composite prepared via $30 \%$-aqueous chitosan solution along with 70\%-polyvinyl alcohol and Ag-NPs was utilized during food packaging and showed antibacterial activity against food poisoning bacterial species [116]. Ag-NPs offer a fundamental mechanism related to antimicrobial properties by causing direct damage to membranes and cell walls of microbes. Such reactions with hydrogen ions and dissolved oxygen executed an oxidized surface and explored its significant role in the antibacterial properties (Fig. 3).

Additionally, nano-Ag has also displayed the property of a "two-layered barrier" toward water-borne pathogens in water treatment plants by showing antimicrobial activity and refining the water quality. As a result, commercial devices based on nano-Ag have been effectively utilized in ceramic microfilters against harmful pathogens in water purification systems [2, 6]. Recently, a more detailed study was conducted on deciphering the antimicrobial mechanism of nano-Ag materials that revealed distinct mechanisms, such as blocking biochemical pathways, DNA damage, protein complexes, and membrane disruption $[4,9]$.

In another instance, Xiu et al. [8] suggested that the low composition of nano- $\mathrm{Ag}$ or $\mathrm{Ag}$ ions might be causing a hermetic reaction with $E$. coli growth. Concomitantly, nano-encapsulation of NPs in bioactive forms has been a reliable and efficient method of increasing antimicrobial activity resulting in elevating the number of incorporated compounds in the liquid-solid interfaces or water-rich phases. These sites are significantly favored microbial growth, hence, specifically targeted by M-NPs [14, 15]. Furthermore, nano-encapsulation of bioactive compounds enhances the physical stability of compounds and defends them from food-pathogen interactions $[14,15]$.

\section{ZnO-based NPs}

The application of ZnO-NPs enhances efficient food packaging due to UV blocking and being cheaper than Ag-NPs shows improved antimicrobial activities. The absorption of ZnO-NPs in films can significantly increase its packaging features including durability, blockage 


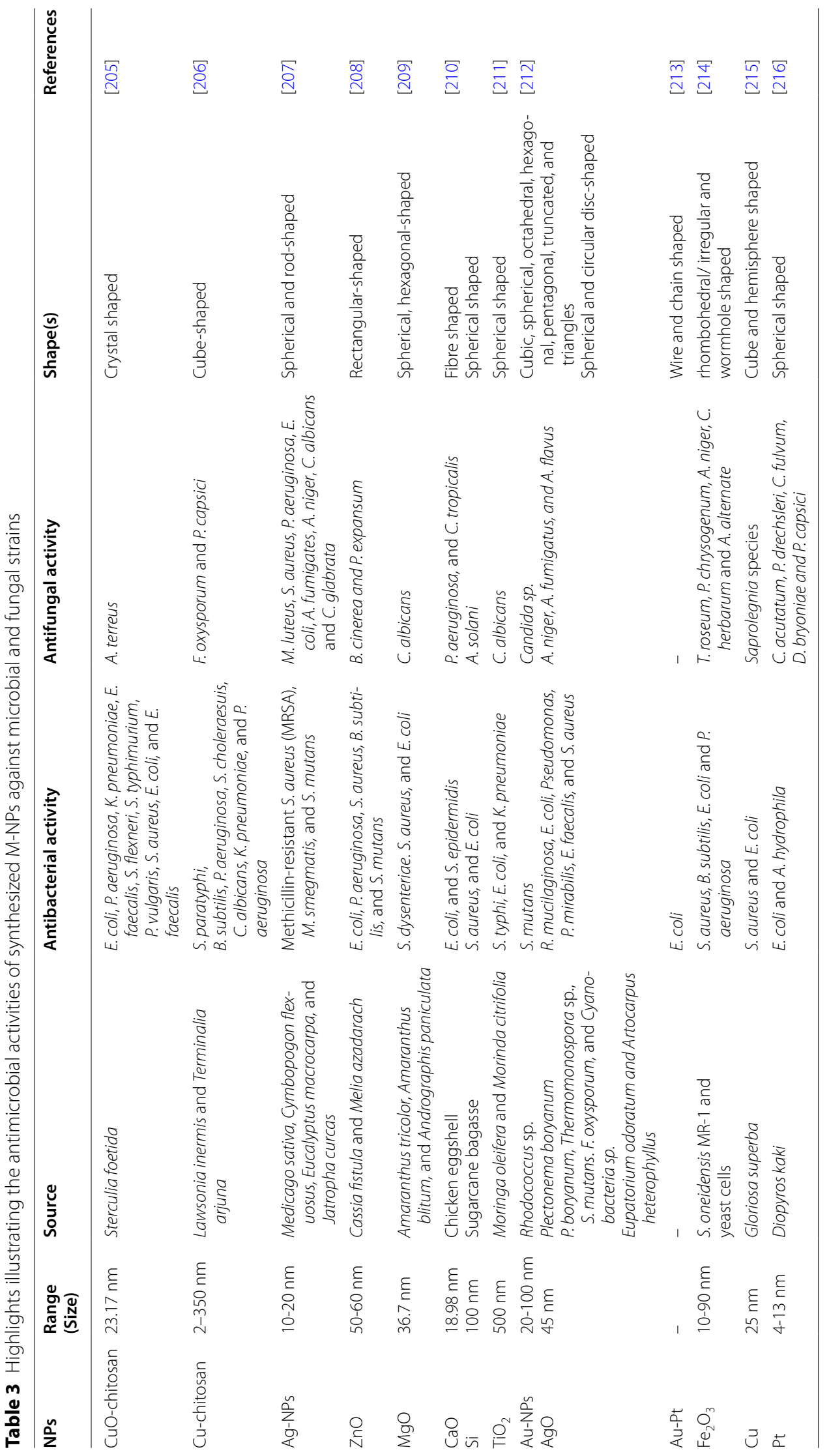




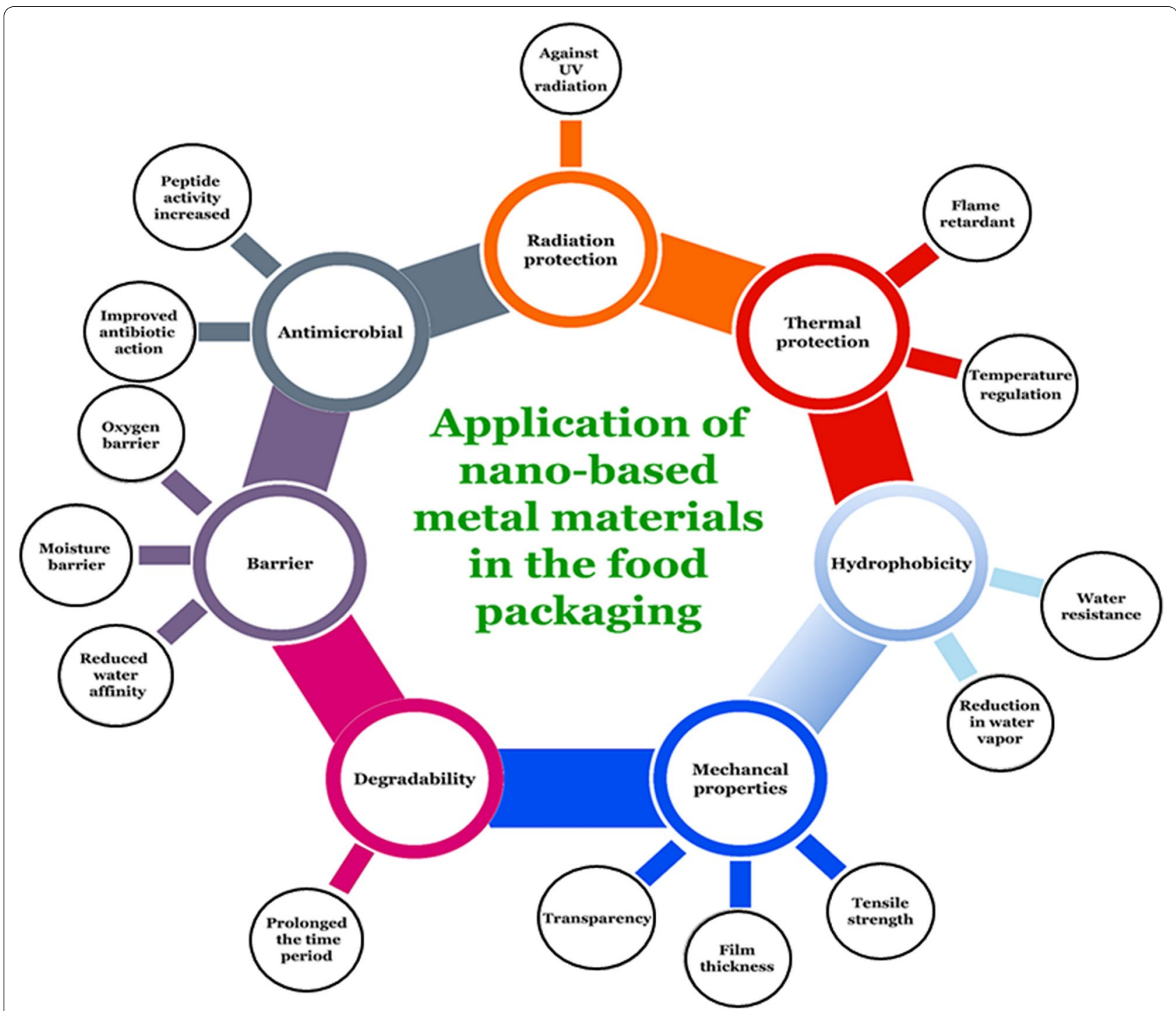

Fig. 3 Applications and characteristics of nano-based metal-materials in food packaging

properties, and mechanical strength [116-120]. The PLA (polylactic acid) matrix and $\mathrm{ZnO}$-dispersed NPs are effectively decreased the permeability efficiency of penetrant molecules (PLA enhancing the efficiency of the diffusive route). Moreover, these eco-friendly packaging components are also demonstrated bactericidal activity. In another instance, Prakash et al. [118] demonstrated that the alteration of the film derived from bacterial cellulose through BC-PPy-ZnO (polypyrrole-Zinc oxide) nanocomposite as active and smart food packaging. It increases food storage by restricting the pathogen growth in meat products.

$\mathrm{ZnO}-\mathrm{NPs}$ derived from Catharanthus roseus (leaf extract) performed significant antibacterial properties against B. thuringiensis, S. aureus, P. aeruginosa, E. coli
P. aeruginosa, $B$. subtilis, and $C$. jejuni were much sensitive to these NPs (Table 3). ZnO-NPs showed antibacterial activity on both gram-negative and gram-positive bacteria.

Zn-NPs also exhibited antifungal activity against $P$. expansum and Botrytis cinerea in an elevated dose of more than $3 \mathrm{mmol} / \mathrm{L}$. These results suggested that $P$. expansum is more sensitive than $B$. cinerea [117-119]. These NPs are a good antimicrobial agent for food packaging in micro-concentration against foodborne pathogens like Klebsiella pneumonia, S. aureus, P. aeruginosa, and $E$. coli. These can be described using techniques such as transmission electron microscopy (TEM) transform infrared (FT-IR) spectroscopy, $\zeta$-potential, magnetic resonance spectroscopy, and dynamic light scattering [116]. 


\section{Cu-based NPs}

Nanocomposites of $\mathrm{Cu}$ polymer inhibit the growth of bacterial cells via various methods including degradation of cell wall components/carboxyl/amines in $\mathrm{N}$-acetylmuramic acid and $\mathrm{N}$-acetylglucosamine in the peptidoglycan layer and sulfhydryl groups on cell membranous proteins. Such destabilization in membrane proteins at cell walls subsequently degrades the bacterial membrane, cell wall components genetic structures, and generates oxidative species production causes bacterial death. Similarly, CuNPs binds to the surface of the bacterial cells via various molecular interactions and electrostatic like adherent forces. Secondly, these encapsulated NPs penetrate the cell through the membrane or outer cell surface through direct diffusion and endocytosis [120-123].

The developed $\mathrm{Ag}-\mathrm{Cu}$ NPs based nanocomposite showed improved oxygen barrier efficacy, UV light, and mechanical strength. However, the film confined antimicrobial activity against $S$. typhimurium and L. monocytogenes were also more effective against gram-positive and gram-negative bacteria [124]. Bimetallic Ag-Cu NPs and PLA composite are prepared films along with cinnamon oil. The efficacy of the film was evaluated against $L$. monocytogenes, C. jejuni, and S. typhimurium. The pathogenic growth was remarkably declined with the addition of $50 \%$ cinnamon essential oil packaging [124].

Interestingly, the metal-oxide polymers are prepared using nanocomposite films, poly- $\varepsilon$ - caprolactone biodegradable compound, disposed of ethylene terephthalate oil and zinc oxide-copper oxide have indicated efficient mechanical properties in domestic packaging. Such copper-polymer nanocomposite films have already demonstrated antimicrobial activity against $E$. coli, Streptococcus spp., S. aureus, Pseudomonas spp., and S. cerevisiae [125].

\section{Other M-NPs used in food packaging}

Mixing of different metal-polymers matrices indicates various properties including structure functionalities, highly regularized pores, ordered crystalline structures, and large surface areas, provides a new insight of blending components for useful applications [123, 126]. In a published study, the Ag-doped $\mathrm{TiO}_{2}$ colloids showed antimicrobial activity against $C$. albicans, S. typhimurium, B. subtilis, S. aureus, and $E$ coli. The fusion of $\mathrm{Au}-$ NPs and Ag-NPs encapsulated within chitosan films, showed promising antimicrobial properties that suppress microbial growth like C. albicans, $P$. aeruginosa, S. aureus, Aspergillus niger [127, 128]. A combination of vinyl alcohol/titanium/chitosan/ nanocomposite based on $\mathrm{TiO}_{2}-\mathrm{NPs}$ reduced the food spoilage microbes and helped in the storage of cheese after packaging (Table 3 )
[129]. Moreover, information on the application and characteristics of M-NPs are summarized in Fig. 3.

\section{Promises of M-NPs as antimicrobial agent}

The possible antimicrobial activity of NPs may follow any of the mechanisms such as oxidizing cell components, production of secondary products such as heavy metal ions, or ROS. These directly interact with cells of microbes by penetration or disrupting the cell envelope or interfering in transmembrane electron transfer. All these alterations ultimately ended with cell death $[84,85]$.

Ag-NPs are the most widely used antimicrobial agent in the field of nanotechnology against multiple pathogenic strains, viruses, and fungi (Table 3) [130, 131]. Ag-NPs target the outer and cytoplasmic membranes, disrupt the function of respiratory chain enzymes, triggers the production of ROS, and can induce the bacteriostatic effect by binding Ag to the protein, enzymes, and DNA [132-134]. The noteworthy antimicrobial activity of AgNPs in the agar films was reported by Rhim et al. [135] against the E. coli and Listeria monocytogenes. In another similar report, a strong antimicrobial activity was documented against the Salmonella spp by PLA/Au-OMMT nanocomposite.

The different matrix components with M-NPs showing effectiveness against microbial growth and maintain food quality via regulating metabolic cascades are explained in Table 4 [133]. The antimicrobial effect of cellulose/chitosan nanocomposite films and cellulose/chitosan silver was examined showing the higher antimicrobial activity in films with Ag-NPs [134-137]. The Ag-NPs incorporated on films of sodium alginate were implemented on the food packing against E. coli and S. aureus [138]. The size of the Ag particle is very important for antimicrobial efficacy. The grapheme oxide is incorporated over Ag-NPs where the size is regulated by temperature and $\mathrm{AgNO}_{3}$ concentration. These nanohybrids showed antimicrobial properties against the Pseudomonas aeruginosa, E. coli, Staphylococcus aureus, and Candida albicans (Table 3) [139].

The CuNPs showed antimicrobial activity after the 4-h exposures against the Saccharomyces cerevisiae, S. aureus, E. coli, and L. monocytogenes [140]. The polyurethane nanofibers containing CuNPs was showing higher antibacterial activity against the $B$. subtilis and $E$. coli [141]. CuNPs are having several toxic effects including ROS production, protein oxidation, lipid peroxidation, and DNA degradation [142]. The ZnNPs on incorporation with the plastic matrix have antifungal and antimicrobial activity [143].

Other antimicrobial NPs such as $\mathrm{MgO}, \mathrm{TiO}_{2}$, and $\mathrm{ZnO}$ are also having a role in food packaging by showing photo-catalytic disinfection and UV blockers. $\mathrm{TiO}_{2}-\mathrm{NPs}$ 
Table 4 Matrix components used during migration of metal particles and their effect on the growth of microbes

\begin{tabular}{|c|c|c|c|c|c|c|c|}
\hline Matrix & Nanomaterial & Size & $\begin{array}{l}\text { Analytical } \\
\text { method } \\
\text { used }\end{array}$ & Amount used & Migration amount & Effect & References \\
\hline $\begin{array}{l}\text { PE film } \\
\text { PVA-Chitosan film }\end{array}$ & $\begin{array}{l}\mathrm{TiO}_{2} \\
\mathrm{TiO}_{2}\end{array}$ & $\begin{array}{l}20-80 \mathrm{~nm} \\
17-170 \mathrm{~nm}\end{array}$ & $\begin{array}{l}\text { ICP-MS } \\
\text { ICP-MS }\end{array}$ & $\begin{array}{l}250 \mu \mathrm{g} / \mathrm{g} \mathrm{Ti} \\
0.1 \% \mathrm{w} / \mathrm{V}\end{array}$ & $\begin{array}{l}\text { AA: } 0.23,1.1,2.0 \\
\text { E: } 0.08,0.10 \text { and } 0.35 \\
\text { Traces }\left(4 \times 10^{-3}\right)\end{array}$ & $\begin{array}{l}\text { Suppress growth } \\
\text { of Pseudomonas, } \\
\text { Rhodotorula, and } \\
\text { micro-organisms } \\
\text { growth in packed } \\
\text { pears } \\
\text { UV barrier proper- } \\
\text { ties, reduction in } \\
\text { the growth of for } \\
\text { Salmonella, E. coli, } \\
\text { and S. aureus }\end{array}$ & [187] \\
\hline PLA & $\mathrm{TiO}_{2}$ and $\mathrm{Ag}$ & Nanosize & ICP-AES & $0.5 \% \mathrm{w} / \mathrm{w}$ & $\begin{array}{l}A A<0.59 \\
E<0.17\end{array}$ & $\begin{array}{l}\text { Inhibits physiological } \\
\text { processes (respira- } \\
\text { tion, ethylene pro- } \\
\text { duction), growth } \\
\text { of yeast, molds and } \\
\text { maintain the qual- } \\
\text { ity of bayberries }\end{array}$ & [189] \\
\hline PLA & $\mathrm{TiO}_{2}$ and $\mathrm{Ag}$ & $10-15 \mathrm{~nm}$ & ICP-AES & $3 w / w$ & $\mathrm{H}: 18.8-21.2$ & $\begin{array}{l}\text { Hinder the oxidation } \\
\text { of fish oil }\end{array}$ & [190] \\
\hline LDPE & $\mathrm{ZnO}$ & $20-400 \mathrm{~nm}$ & - & $0.25 \% \mathrm{w} / \mathrm{w}$ & $<0.12$ & $\begin{array}{l}\text { Inhibit the growth } \\
\text { of Salmonella in } \\
\text { liquid egg }\end{array}$ & [191] \\
\hline LDPE & $\mathrm{ZnO}$ and $\mathrm{Ag}$ & $\begin{array}{l}70 \mathrm{~nm} \mathrm{ZnO}, 10 \mathrm{~nm} \\
\mathrm{Ag}\end{array}$ & ICP-MN & $10 \% \mathrm{w} / \mathrm{w}$ & $\mathrm{Zn}-407, \mathrm{Ag}<0.17$ & $\begin{array}{l}\text { Reduce the growth } \\
\text { of } E \text {. coli and } \\
\text { prevent phytodeg- } \\
\text { radation }\end{array}$ & [192] \\
\hline LDPE & $\mathrm{CuO}$ & $50 \mathrm{~nm}$ & AAS & $1 \% w / w$ & 38 & $\begin{array}{l}\text { Decrease the growth } \\
\text { of coliform bac- } \\
\text { teria and reduce } \\
\text { microbial growth }\end{array}$ & [193] \\
\hline PLA & $\mathrm{Al}_{2} \mathrm{O}_{3}$ & $25 \mathrm{~nm}$ & ICP-MS & $25 \mathrm{~nm}$ coating & Al-500 & $\begin{array}{l}\text { Improve gas barrier } \\
\text { properties }\end{array}$ & [194] \\
\hline LDPE & $\mathrm{Ag}, \mathrm{TiO}_{2}$ and $\mathrm{SiO}_{2}$ & $40-60 \mathrm{~nm}$ & ICP-MN & $1 \% \mathrm{w} / \mathrm{w}$ & - & $\begin{array}{l}\text { Lowers the respira- } \\
\text { tion rate, ethylene } \\
\text { scavenging and } \\
\text { maintain the nutri- } \\
\text { ent quality }\end{array}$ & [195] \\
\hline
\end{tabular}

are the most promising one among all. These are active under the UV light radiations and display antimicrobial activity against Vibrio parahaemolyticus, S. choleraesuis, and L. monocytogenes only in light conditions [144-148]. The probable mechanism of action of $\mathrm{TiO}_{2}$ as the antibacterial activity involves the attack of oxidative entities on the inner or outer cell membrane of bacteria, DNA damage, and also the altered Coenzyme $A$ dependent activity [149].

The photoactivated biocidal activity $\mathrm{TiO}_{2}$ was reported against the nine bacterial species such as Bacillus sp., $B$. stearothermophilus, Erwinia caratovora, E. coli, L. plantarum, $P$. fluorescens, $P$. jadinii, S. aureus, and Z. rouxii [147]. The $\mathrm{TiO}_{2}$-coated plastic films showed antimicrobial activity against the Penicillium expansum on the spoilage of lemons, apples, and tomatoes [151]. Furthermore, $\mathrm{ZnO}$ has also shown better antibacterial activity with the reduction in particle size and also required visible light for activation $[149,150]$. It induces the destruction of cell wall integrity, shoots in ROS production, and liberation of $\mathrm{Zn}^{2+}$ antimicrobial ions [151]. Similarly, $\mathrm{ZnO}$ was observed to be the most effective antibacterial agent against $S$. aureus (Fig. 2).

\section{Health risks, toxicity, and drawbacks of using NPs for food packaging}

Despite a hundreds of papers published in nanotechnology to date, still, numerous publications focus more on the negative impacts of NPs. As per the literature, ingestion, inhalation, or accidental exposure of M-NPs during 
packaging and processing creates immense health risks in workers [152-154]. It even includes lysosomal damage, cardiovascular diseases, lung tumors, blood clotting, and induced cytotoxicity (Fig. 4) [152-154].

In this context, the spleen and liver are chiefly responsible for the passage of NPs, guiding their transportation from the intestine to the bloodstream. Studies on Ag- and $\mathrm{TiO}_{2}$-NPs demonstrated that these substances are insoluble and significantly accumulated in organs [155]. Such unintentional migration through packaged products may raise several serious health concerns to even consumers. The migration of these M-NPs solely depends upon the chemical and physical properties of polymer complexes and food [156]. Additionally, several other regulating parameters such as particle size, solubility, molecular weight, concentration, polymer viscosity, temperature, $\mathrm{pH}$ value, the diffusivity of a compound in polymer, contact time, mechanical strength, composition, and matrix of food. However, concentration, route of an entrance, toxicity, and duration of exposure also affect the state and susceptibility of an organism [157].

In comparison, NPs increase their possibilities of interaction that ultimately lead to various hazardous effects. For instance, nano- $\mathrm{TiO}_{2}$ and nano-Ag induced high toxicity causes carcinogenicity and genotoxicity, even larger-sized $\mathrm{ZnO}$ is less toxic indicating the role of NPs diameter. Inhalation of $\mathrm{Nano}-\mathrm{TiO}_{2}\left(10 \mathrm{mg} / \mathrm{m}^{3}\right)$ enhances the risk of lung tumor. $\mathrm{ZnO}$ at $10 \mu \mathrm{g} / \mathrm{ml}$ concentration inhibits the cell proliferation, viability of Caco-2 cells concentration, and elevates ROS production along with super oxidase levels; implies an oxidative stress response (Fig. 2) [158]. Few studies had reported that enhanced $\mathrm{TiO}_{2}$-NPs can distort the structure of microvilli in epithelial cells of intestinal tissue and affects the normal nutrient absorption. Moreover, systemic inhalation of MgO-NPs migrates to the olfactory bundle via sensory nerves cause an ill effect on various parts of the brain. These NPs become migratory via the bloodstream and may affect the lining of blood vessels even crossing blood-brain barriers in the fetus [159].

In this context, the regulatory system is crucial to access the significant risks that emerge by the use of MNPs in the food sector [2, 158]. According to European Commission regulation (ECR), number 2015/2285, the European food safety authority (EFSA) must confirm that for the association of engineered NPs in food safety assessment was carried out using the modern generation of analytic approaches. In the united states (US), 258/97 regulation stipulates that if NPs used as active ingredients it has to be definitely used for fresh food. Another regulation no. 133/2008 by European commission term "food additive and its composition" as evaluation mark, as a new and safe material before used commercially $[2$, 3].

Besides these issues, M-NPs usage triggered nonbiodegradable concerns affecting environmental health

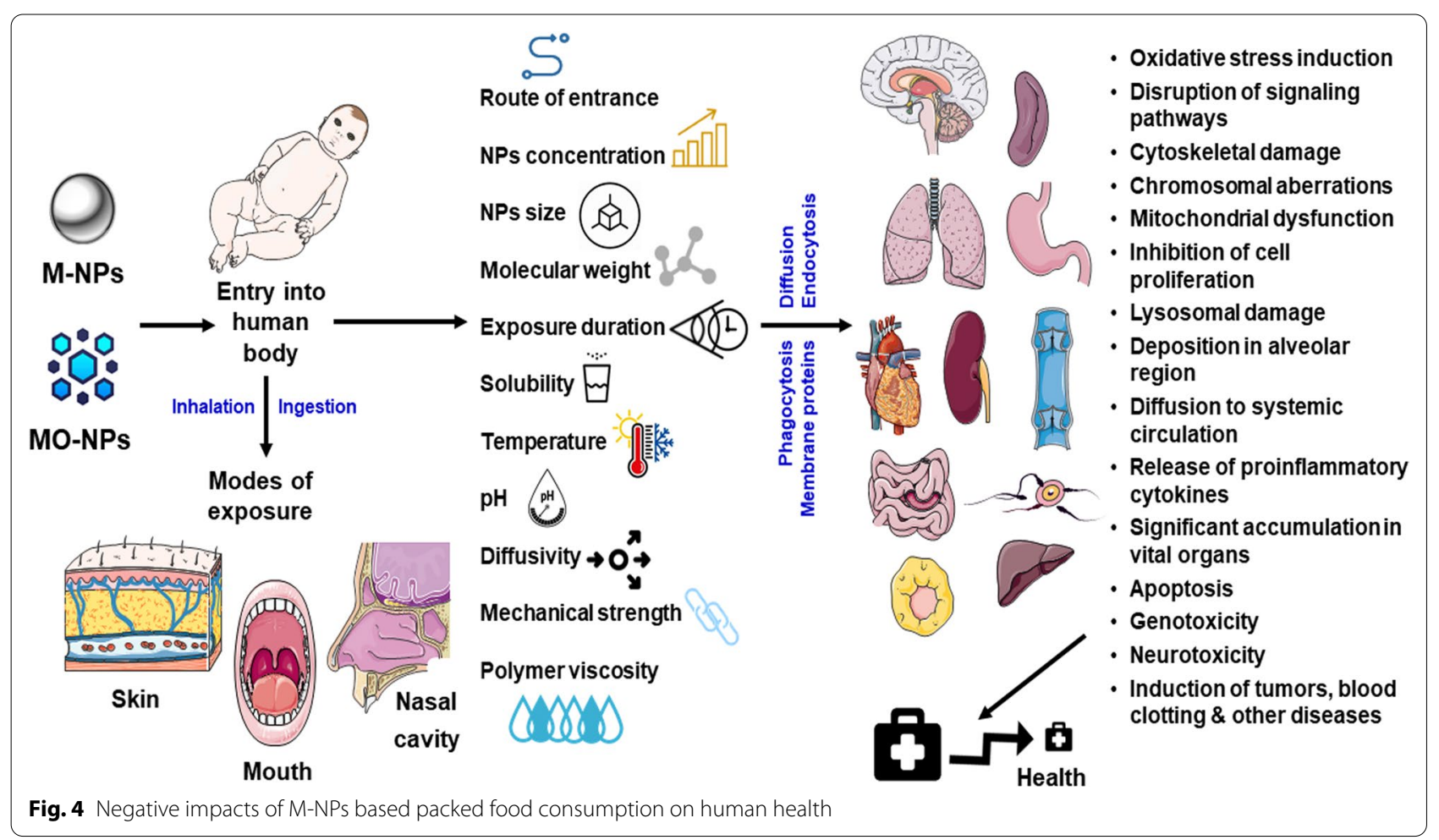


creates eco-toxicity leading to a vague situation for all exciting communities on the planet. Nevertheless, additional meticulous information and scientific data are required at this infancy stage of M-NPs applications in food packaging [202-204]. Although, toxicity during migration, distribution, absorption, metabolism and finally their everlasting residues should be evaluated and quantified the risk assessment to the consumer level [85].

\section{Perceptions and future perspectives}

Since its inception, nanotechnology shows extensive and fruitful results in developing new products but enhances safety issues that deserve well attention. Therefore, understanding numerous techniques with diversified roles draws many variegate and safety conclusions regarding toxicity. The assessment of recent development in M-NPs plays a substantial function and the assessment of adverse outcomes. Several benefits of projected food nanotechnology like the use of stable emulsions, less fat, better taste in mayonnaise, ice-cream, canned stuff taste masking of additives including fish oils, enhanced level of nutrients, optic appearance, antimicrobial action, supplements, and other nano-textured food prepared after killing of pathogenic microbes. It also offers flexibility in packaging, moisture, temperature, gas barrier activities and helps in maintaining active packaging using M-NPs. Furthermore, it inhibits the growth of microbial pathogens on the plastic surface. No doubt, these second-generation NPs add flexibility in preservation activity, antimicrobial activities, binding bioavailability with desired food and polymer extract without hinders to the mechanical strength, gasses movements, and flavors.

Moreover, water filtration, food clarification, plant extract waste, and other undesired components still need more progression in food industry research. The degradation, transformation of carbon-based carrier substrates during metal incorporation in food products and the environment remains a prime challenge toward acceptance of these techniques. Recently, fresh fruit cutting, food packaging, processing, storage, transportationrelated industries have rapidly enhanced. These M-NPs based applications help in the improvement of food packaging to sustain food preservation and shelf life (Table 5).

The advancement of M-NPs requires more research that is not limited to packaging and processing but expands toward quality traits, nutraceutical values, and

Table 5 Role of Metal complexes and their successful application in food packaging

\begin{tabular}{|c|c|c|c|}
\hline M-NPs/Polymeric complex & Targeted microbes & Successful food application & References \\
\hline $\begin{array}{l}\text { Cellulose-Ag-NPs } \\
\text { HPMC-Ag-NPs } \\
\text { PVC-Ag-NPs } \\
\text { EVOH-Ag-NPs }\end{array}$ & $\begin{array}{l}\text { Aerobic bacteria, lactic acid bacteria, and Pseudomonas } \\
\text { sp. } \\
\text { E. coli, S. aureus } \\
\text { S. aureus, E. coli, and total mesophilic bacteria } \\
\text { L. monocytogenes and Salmonella sp. }\end{array}$ & $\begin{array}{l}\text { Beef-meat } \\
- \\
\text { Beef } \\
\text { Cheese, chicken }\end{array}$ & {$[196]$} \\
\hline $\begin{array}{l}\text { Cellulose-Ag-NPs } \\
\text { Calcium alginate/Ag-montmorillonite } \\
\text { NPs }\end{array}$ & $\begin{array}{l}\text { Aerobic bacteria, Psychotropic bacteria, Yeasts, and molds } \\
\text { Aerobic bacteria }\end{array}$ & $\begin{array}{l}\text { Freshly-cut melon } \\
\text { Freshly-cut carrot }\end{array}$ & {$[181]$} \\
\hline Pullulan-Ag-NPs & $\begin{array}{l}\text { L. monocytogenes and S. aureus } \\
\text { L. monocytogenes and S. aureus }\end{array}$ & $\begin{array}{l}\text { Turkey meat } \\
\text { Poultry products, meat }\end{array}$ & {$[42]$} \\
\hline Pullulan-ZnO-NPs & E. coli, L. monocytogenes, and S. aureus & Poultry products, meat & {$[197]$} \\
\hline $\begin{array}{l}\text { Agar hydrogel, } \\
\text { Ag-montmorillonite NPs } \\
\text { Sodium alginate-CaCl} / 2 / A g-N P s \\
\text { LDPE-Ag-NPs/ZnO-NPs } \\
\text { Cellulose-Cu NPs } \\
\text { Oriented PP. coated film, } \mathrm{TiO}_{2} \\
\text { Polyurethane Ag-NPs }\end{array}$ & $\begin{array}{l}\text { Pseudomonas } \\
- \\
\text { Pseudomonas, Enterobacter and } \\
\text { Escherichia coli } \\
\text { Yeast, mold, and total aerobic bacteria } \\
\text { S. cerevisiae, S. epidermis and S. aureus } \\
\text { S. aureus and E. coli } \\
\text { S. aureus and E. coli }\end{array}$ & $\begin{array}{l}\text { Cheese } \\
\text { - } \\
\text { Cheese } \\
\text { Orange juice } \\
\text { Fruit juice } \\
\text { Lettuce } \\
\text { Lettuce }\end{array}$ & {$[198]$} \\
\hline $\begin{array}{l}\text { Sodium alginate-Ag-NPs } \\
\text { Hydroxypropyl methylcellulose Cu NPs } \\
\text { Chitosan- } \mathrm{TiO}_{2}\end{array}$ & $\begin{array}{l}\text { E. coli and S. aureus } \\
\text { S. aureus, B. aureus and Salmonella sp. } \\
\text { S. aureus, Salmonella sp. and E. coli }\end{array}$ & $\begin{array}{l}\text { Pears } \\
\text { Meat } \\
\text { Cheese, chicken }\end{array}$ & {$[199]$} \\
\hline $\begin{array}{l}\mathrm{LDPE} / \mathrm{Ag}-\mathrm{NPS} \\
\mathrm{LDPE}-\mathrm{Ag}-\mathrm{NPs} / \mathrm{TiO}_{2} \\
\text { Polyethylene-Ag/ } \mathrm{TiO}_{2}-\mathrm{NPs} \\
\text { Polyethylene }-\mathrm{Ag} / \mathrm{TiO}_{2} \mathrm{NPs} \\
\mathrm{HDPE} / \text { Marigold extract-TiO }\end{array}$ & $\begin{array}{l}\text { Aerobic bacteria } \\
\text { Aerobic bacteria } \\
\text { Lactobacillus and Penicillium } \\
\text { S. aureus and E. coli } \\
\text { Salmonella sp. }\end{array}$ & $\begin{array}{l}\text { Barberry } \\
\text { Strawberry } \\
\text { Fresh-apple, carrots, milk powder } \\
\text { White slice bread, cheese, milk } \\
\text { powder } \\
\text { Soybean oil }\end{array}$ & [153] \\
\hline Whey protein, cast film, $\mathrm{TiO}_{2}$ & S. aureus and Salmonella sp. & Meat & {$[200]$} \\
\hline LDPE /Blown film $\mathrm{TiO}_{2}$ & Pseudomonas, Rhodotorula & Almonds & {$[201]$} \\
\hline
\end{tabular}


natural flavors of the product. The transfer of metal particles along with the foodstuff is a primary step. It needs more intense clarification and validation on the disadvantages such as persistence of metal ion, cost-effectiveness, uncontrolled bioactive release, toxicity percentage, stability inactivity after migration, and public acceptance.

\section{Concluding remarks}

With the advent of awareness of health, nutrition, food safety, and global food demand, a huge demand for adopting new technologies to enhance the quantity and quality of food products has emerged. The importance develops from the M-NPs $\left(\mathrm{ZnO}, \mathrm{SiO}_{2}, \mathrm{CeO}_{2}, \mathrm{TiO}_{2}, \mathrm{Ag}-\mathrm{NPs}\right.$, and $\mathrm{Au}$ ) nanoscale characteristics, oxygen scavengers, physicochemical properties, and antimicrobial activities. M-NPs are efficient antimicrobial agents and effectively inhibit the growth of a diverse range of food-borne pathogenic bacteria, mold, and fungi. Polymers used for encapsulation of M-NPs play a significant role as a carrier vehicle without hindering the natural properties. These polymer-metal complexes are assumed to be promising in increasing shelf life and are ecologically essential for food packaging. Additionally, such post-processing technologies at the nanoscale level offer direct incorporation of antimicrobial compounds in space around the foodstuffs and ensure their quality during storage at the long interval.

Furthermore, active packaging using biocidal substances overcomes the challenges of target-based delivery, the life span of the product, nutrients degradation, and stability of packaging compounds. Intensive research has evaluated the significant role of improving food quality, toxicity monitoring, and degradation after transport to help in understanding functional properties. Despite these, the intake of metallic particles with food creates potential health issues and is always at risk of public rejection. Moreover, toxicological aspects and resistance of microbes toward M-NPs still need extended research validations. The nanotechnologies and their potential uses need a standard regulatory framework and labelling of food to address the consumer demands and their commercial adoption to reduce nano-enabled food. In summary, toxicity concerns have raised numerous questions about potential implementation to ensure the safe use of M-NPs in food industries.

\footnotetext{
Abbreviations

NPs: Nanoparticles; M-NPs: Metal-based nanoparticles; FAOs: Food and agriculture organization; FLI: Food Loss Index; UNEP: United nations environment programme; FWl: Food waste index; WHO: World health organization; CNTs: Carbon nanotubes; PET: Polyethylene terephthalate; PP: Polypropylene; PE: Polyethylene; AgNPs: Silver nanoparticles; Silica NPs: Si NPs; nano-ZnO: Nano Zinc oxide; nano- $\mathrm{Ce}_{2} \mathrm{O}_{4}$ : Nano cerium oxide; nano- $\mathrm{TiO}_{2}$ : Nano titanium oxide; nano-Ag: Nano silver: nanosilver; Au: Gold; Ag: Silver; Zn: Zinc; $\mathrm{TiO}_{2}$ : Titanium
}

oxide; $\mathrm{SiO}_{2}$ : Silicon oxide; $\mathrm{MgO}$ : Magnesium oxide; $\mathrm{ZnO}$ : Zinc oxide; PCR: Polymerase chain reaction; $\mathrm{AgNO}_{3}$ : Silver nitrate; $\mathrm{NaBH}_{3}$ : Sodium cyanoborohydride; $\mathrm{ZnO}-\mathrm{SnO}_{2}$ : Zinc oxide Tin oxide; BSA: Bisphenol A; MOs: Metal oxides; MMOs: Mixed metal oxides; UV: Ultraviolet; PLA: Polylactic acid; CuO: Copper oxide; Pd: Palladium; Pt: Platinum; Ag: Silver; Au: Gold; Ti: Titanium; N: Nitrogen; Mg-ONPs: Magnesium oxide nanoparticles; CNTs: Carbon nanotubes; Au-NPs: Gold nanoparticles; Cu-NPs: Copper nanoparticles; CuO-NPs: Copper oxide nanoparticles; MgO-NPs: Magnesium oxide nanoparticles; IHPC: Institute for Health and Consumer Protection; ROS: Reactive oxygen species; POD: Pyrogallol peroxidase; MDA: Malondialdehyde; OMMT: Organic montmorillonite; Zn ${ }^{2+}$ : Zinc; BC-PPy: Bacterial cellulosepolypyrrole; Cu: Copper; Zn: Zinc; Ag: Silver; PE film: Polyethylene film; ICP-MS: Inductively coupled plasma mass spectrometry; PVA: Polyvinyl allyl; PLA: Poly-lactic acid; ICP-AES: Inductively coupled plasma atomic emission spectroscopy; LDPE: Lowdensity polyethylene; $\mathrm{CaCl}_{2}$ : Calcium dichloride; PVC: Polyvinyl chloride; EVOH: Ethylene vinyl alcohol; HDPE: High Density Poly Ethylene; GC-MS: Gas chromatographymass spectroscopy; Au@AgNP: Gold coated silver nanoparticles; MWCNT: Multiwalled carbon sanotubes; SERS: Surface enhanced Raman spectroscopy; ECR: European commission regulation; US: United states; EFSA: European food safety authority.

\section{Acknowledgements \\ Not applicable}

\section{Authors' contributions}

The manuscript was designed and constructed primarily by $\mathrm{AH}$ and established by AK, AC, HK, and SM. AK reviewed the literature, HK and SM examined the draft and prepared the table and figure sections. AC, AK, and SM were actively involved in manuscript writing, and $\mathrm{AH}$ offered crucial advice and examined the manuscript on every step of writing, and revised the manuscript as per the peer reviewer's comments. All authors read and approved the final version of the manuscript.

\section{Funding}

Not applicable.

Availability of data and materials

Not applicable.

\section{Declarations}

Ethics approval and consent to participate

Not applicable.

\section{Consent for publication}

Not applicable.

\section{Competing interests}

The authors declare that they have no conflict of interest.

\section{Author details}

${ }^{1}$ Department of Botany, Punjab Agricultural University, Ludhiana 141004, India. ${ }^{2}$ International Centre for Genetic Engineering and Biotechnology, Aruna Asaf Ali Marg, New Delhi 110067, India. 'Wolaita Sodo University, P.O. Box: 138, Wolaita, Ethiopia.

Received: 22 March 2021 Accepted: 13 August 2021

Published online: 26 August 2021

\section{References}

1. Sarah RW, Madeleine AR, Lisa GC, Sarah G, Roger G, Jessica EH, et al. Climate change effects on biodiversity, ecosystems, ecosystem services, and natural resource management in the United States. Sci Total Environ. 2020;733:137782.

2. Luo N, Olsen TL, Liu YA. Conceptual framework to analyze food loss and waste within food supply chains: an operations management perspective. Sustainability. 2021;13:927. 
3. Nicastro R, Carillo P. Food loss and waste prevention strategies from farm to fork. Sustainability. 2021;13:1-23.

4. Qu X, Alvarez PJ, Li Q. Applications of nanotechnology in water and wastewater treatment. Water Res. 2013;47:3931e3946.

5. Aruguete DM, Kim B, Hochella MF, Ma Y, Cheng Y, Hoegh A, Liu J, Pruden A. Antimicrobial nanotechnology: its potential for the effective management of microbial drug resistance and implications for research needs in microbial nanotoxicology. Environ Sci Process. 2013:15:93e102.

6. Alfadul SM, Elneshwy AA. Use of nanotechnology in food processing, packaging and safety e review. Afr J Food Agric Nutr Dev. 2010;10:2720e2739.

7. Ajitha B, Reddy YAK, Reddy PS. Biosynthesis of silver nanoparticles using Plectranthus amboinicus leaf extract and its antimicrobial activity. Spectrochim Acta Mol Biomol Spectrosc. 2014;128:257e262.

8. Peter-Varbanets M, Zurbrügg C, Swartz C, Pronk W. Decentralized systems for potable water and the potential of membrane technology. Water Res. 2009;43:245e265.

9. Bata-Vidács I, Adányi N, Beczner J, Farkas J, Székács A. Nanotechnology and microbial food safety. In: Méndez-Vilas A, editor. Microbial pathogens and strategies for combating them: science, technology and education. Formatex; 2013. p. 155e169.

10. Xiu ZM, Zhang QB, Puppala HL, Colvin VL, Alvarez PJ. Negligible particle-specific antibacterial activity of silver nanoparticles. Nano Lett. 2012;12:4271e4275.

11. Zahra M, Seid MJ. Nanoparticles/nanofibers for checking adulteration/spoilage of food products. Handbook of food nanotechnology. Academic Press; 2020. p. 459-492

12. Ball AS, Patil S, Soni S. Introduction into nanotechnology and microbiology. Methods Microbiol. 2019;46:1-18.

13. Zahin N, Anwar R, Tewari D. Nanoparticles and its biomedical applications in health and diseases: special focus on drug delivery. Environ Sci Pollut Res. 2020;27:19151-68.

14. Weiss J, Gaysinsky S, Davidson M, McClements J. Nanostructured encapsulation systems: food antimicrobials. In: Barbosa-Cánovas GV, Mortimer A, Lineback D, Spiess W, Buckle K, editors. Global issues in food science and technology. Amsterdam: Elsevier Inc; 2009. p. 425 e479.

15. Donsi F, Annunziata M, Sessa M, Ferrari G. Nanoencapsulation of essential oils to enhance their antimicrobial activity in foods. LWT e Food Sci Technol. 2011;44:1908e1914.

16. Ravichandran M, Hettiarachchy NS, Ganesh V, Ricke SC, Singh S. Enhancement of antimicrobial activities of naturally occurring phenolic compounds by nanoscale delivery against Listeria monocytogenes, Escherichia coli O157: H7 and Salmonella Typhimurium in broth and chicken meat system. J Food Saf. 2011;31:462e471.

17. Chopra M, Kaur P, Bernela M, Thakur R. Surfactant assisted nisin loaded chitosan-carageenan nanocapsule synthesis for controlling food pathogens. Food Control. 2014;37:158e164.

18. Dreaden EC, Alkilany AM, Huang X, Murphy CJ, El-Sayed MA. The golden age: gold nanoparticles for biomedicine. Chem Soc Rev. 2012;41:2740-79.

19. Michael JS, Ashley C, Ian S. Metal-based nanoparticles; size, function, and areas. Adv Appl Micro. 2012;80:113-43.

20. Suryavanshi P, Pandit R, Gade A, Derita M, Zachino S, Rai M. Colletotrichum sp. mediated synthesis of sulphur and aluminium oxide nanoparticles and it's in vitro activity against selected foodborne pathogens. LWT-Food Sci Technol. 2017;81:188-94.

21. Rai M, Ingle A, Pandit R, Paralikar P, Gupta I, Chaud MV, Santos CA. Broadening the spectrum of small-molecule antibacterials by metallic nanoparticles to overcome microbial resistance. Int J Pharm. 2017:532:139-48

22. Pandit R, Rai M, Santos CA. Enhanced antimicrobial activity of the food-protecting nisin peptide by bioconjugation with silver nanoparticles. Environ Chem Lett. 2017;15:443-52.

23. Singh M, Sahareen T. Investigation of cellulosic packets impregnated with silver nanoparticles for enhancing shelf-life of vegetables. LWT Food Sci Technol. 2017:86:116-22.

24. Husen A, Siddigi KS. Phytosynthesis of nanoparticles: Concept, controversy and application. Nanoscale Res Lett. 2014;9:229.
25. Siddiqi KS, Husen A, Rao RAK. A review on biosynthesis of silver nanoparticles and their biocidal properties. J Nanobiotechnology. 2018:16:14.

26. Siddiqi KS, Rashid M, Rahman A, Tajuddin HA, Rehman S. Green synthesis, characterization, antibacterial and photocatalytic activity of black cupric oxide nanoparticles. Agric Food Secur. 2020;9:17.

27. Sharma A, Bachheti A, Sharma P, Bachheti RK, Husen A. Phytochemistry, pharmacological activities, nanoparticle fabrication, commercial products and waste utilization of Carica papaya L.: a comprehensive review. Curr Res Biotechnol. 2020;2:145-60.

28. Siddiqi KS, Husen A. Current status of plant metabolite-based fabrication of copper/copper oxide nanoparticles and their applications: a review. Biomater Res. 2020;24:11.

29. Yang L, Chen Y, Shen Y, Yang M, Li X, Han X, Jiang X, Zhao B. SERS strategy based on the modified au nanoparticles for highly sensitive detection of bisphenol A residues in milk. Talanta. 2017;179:37-42.

30. Sarwar MS, Khan MB, Jahan NZ, Ahmad T, Hussain A. Preparation and characterization of PVA/nanocellulose/Ag nanocomposite films for antimicrobial food packaging. Carbohydr Polym. 2018;184:453-64.

31. Ahmed J, Arfat YA, Bher A, Mulla M, Jacob H, Auras R. Active chicken meat packaging based on polylactide films and bimetallic Ag-Cu nanoparticles and essential oil. J Food Sci. 2018;83(5):1299-310.

32. Bhardwaj $H$, Sumana $G$, Marquette CA. A label-free ultrasensitive microfluidic surface Plasmon resonance biosensor for Aflatoxin B1 detection using nanoparticles integrated gold chip. Food Chem. 2020;307:125530.

33. Qian Y, Yu H, He D, Yang H, Wang W, Wan X, Wang L. Biosynthesis of silver nanoparticles by the endophytic fungus Epicoccum nigrum and their activity against pathogenic fungi. Bioproc Biosys Eng. 2013;36:1613-9

34. Alshammari F, HamadJong HH, Byung-Chun K, Irfan AR. The intertwine of nanotechnology with the food industry Saudi. J Biol Sci. 2018;25:27-30.

35. Primoži" CM KŽ, Leitgeb M. (Bio)Nanotechnology in food science-food packaging. Nanomaterials. 2021;11:1-29.

36. Bachheti RK, Abate L, Deepti BA, Madhusudhan A, Husen H. Algae-, fungi-, and yeast-mediated biological synthesis of nanoparticles and their various biomedical applications. In: Kharisov B, Kharissova O, editors. Handbook of greener synthesis of nanomaterials and compounds, volume 1: fundamental principles and methods. Cambridge: Elsevier Inc.; 2021. p. 701-34.

37. Bachheti RK, Fikadu A, Bachheti A, Husen A. Biogenic fabrication of nanomaterials from flower-based chemical compounds, characterization and their various applications: a review. Saudi J Biol Sci. 2020;27:2551-62.

38. Husen A, lqbal M. Nanomaterials and plant potential: An overview. In: Husen A, labal M, editors. Nanomaterials and plant potential. Cham: Springer International Publishing AG; 2019. p. 3-29.

39. Husen A. Introduction and techniques in nanomaterials formulation. In: Husen A, Jawaid M, editors. Nanomaterials for agriculture and forestry applications. Cambridge, USA: Elsevier Inc; 2020. p. 1-14.

40. Bastos AJ, Pérez A, Pérez RC, Serrano N, Fiol N, Poch J, Villaescusa I. Green synthesis of Ag nanoparticles using grape stalk waste extract for the modification of screen-printed electrodes. Nanomaterials. 2018:8:946.

41. Tarannum N, Gautam YK. Facile green synthesis and applications of silver nanoparticles: a state-of-the art review. RSC Adv. 2019;9:34926-34648

42. Khan MJ, Kumari S, Shameli K, Selamat J, Sazili AQ. Green synthesis and characterization of pullulan mediated silver nanoparticles through ultraviolet irradiation. Materials. 2019;12:2382.

43. Ding L, Li X, Hu L, Zhang Y, Jiang Y, Mao Z, Xu H, Wang B, Feng X, Sui X. A naked-eye detection polyvinyl alcohol/cellulose-based pH sensor for intelligent packaging. Carbohydr Polym. 2020;233:115859.

44. Rajan A, Vilas V, Philip D. Catalytic and antioxidant properties of biogenic silver nanoparticles synthesized using Areca catechu nut. J Mol Liq. 2015;207:231-6.

45. Kumar V, Singh DK, Mohan S, Hasan SH. Photo induced biosynthesis of silver nanoparticles using aqueous extract of Erigeron bonariensis and its catalytic activity against Acridine orange. J Photoch Photobio B. 2015:55:39-50. 
46. Ajitha B, Reddy YAK, Reddy PS. Biosynthesis of silver nanoparticles using Momordica charantia leaf broth: evaluation of their innate antimicrobial and catalytic activities. J Photochem Photobio B. 2015;146:1-9.

47. Cicek S, Gungor AA, Adiguzel A, Nadaroglu H. Biochemical evaluation and green synthesis of nano silver using peroxidase from Euphorbia (Euphorbia amygdaloides) and its antibacterial activity. J Chem. 2015;486948:7.

48. Nalavothula R, Alwala J, Nagati VB, Manthurpadigya PR. Biosynthesis of silver nanoparticles using Impatiens balsamina leaf extracts and its characterization and cytotoxic studies using human cell lines. Inter J Chem Tech Res. 2015;7:2460-8.

49. Logaranjan K, Raiza AJ, Gopinath SCB, Chen Y, Pandian K. Shape- and size-controlled synthesis of silver nanoparticles using Aloe vera plant extract and their antimicrobial activity. Nano Res Lett. 2016;11:520-8.

50. Ali M, Kim B, Belfield KD, Norman D, Brennan M, Ali GS. Green synthesis and characterization of silver nanoparticles using Artemisia absinthium aqueous extract- a comprehensive study. Mat Sci Eng C. 2016:58:359-65.

51. Barbinta-Patrascu ME, Badea N, Ungureanu C, Constantin M, Pirvu C, Rau I. Silver-based biohybrids "green" synthesized from Chelidonium majus L. Opt Mater. 2016;56:94-9.

52. Edison TNJI, Apchudan R, Lee YR. Optical sensor for dissolved ammonia through the green synthesis of silver nanoparticles by fruit extract of Terminala chebula. J Cluster Sci. 2016;27:683-90.

53. Karthik R, Hou Y, Chen S, Elangovan A, Ganesan M. Eco-friendly synthesis of Ag-NPs using Cerasus serrulata plant extract-Its catalytic, electrochemical reduction of 4-NPh and antibacterial activity. J Ind Eng Chem. 2016;37:330-9.

54. Sengottaiyan A, Mythili R, Selvankumar T, Aravinthan A, Kamala-Kannan S, Manoharan K, Thiyagarajan P, Govarthanan M, Kim J. Green synthesis of silver nanoparticles using Solanum indicum L. and their antibacterial, splenocyte cytotoxic potentials. Res Chem Intermed. 2016;42:3095-103.

55. Parveen M, Ahmad F, Malla AM, Azaz S. Microwave-assisted green synthesis of silver nanoparticles from Fraxinus excelsior leaf extract and its antioxidant assay. Appl Nanosci. 2016;6:267-76.

56. Sankar R, Manikandan P, Malarvizhi V, Fathima T, Shivashangari KS, Ravikumar V. Green synthesis of colloidal copper oxide nanoparticles using Carica papaya and its application in photocatalytic dye degradation. Spectrochim Acta A Mol Biomol Spectrosc. 2014;121:746-50.

57. Chaudhary P, Fatima F, Kumar A. Relevance of nanomaterials in food packaging and its advanced future prospects. J Inorg Organomet Polym Mater. 2020;30:5180-92.

58. Mustafa F, Andreescu S. Nanotechnology-based approaches for food sensing and packaging applications. RSC Adv. 2020;10:19309-36.

59. Sai-Anand G, Sivanesan A, Benzigar MR, Singh G, Gopalan Al, Baskar AV, Vinu A. Recent progress on the sensing of pathogenic bacteria using advanced nanostructures. Bull Chem Soc Jpn. 2019;92:216-44.

60. Jamkhande PG, Ghule NW, Bamer AH, Kalaskar MG. Metal nanoparticles synthesis: An overview on methods of preparation, advantages and disadvantages, and applications. J Drug Del Sci Tech. 2019;53:1-11.

61. Silva LP, Pereira TM, Bonatto CC. Frontiers and perspectives in the green synthesis of silver nanoparticles. Green synthesis, characterization and applications of nanoparticles. 2019. p. 137-164

62. Abdel-Karim R, Reda Y, Abdel-Fattah A. Nanostructured materials-based nanosensors. J Electrochem Soc. 2020;167:037554.

63. Peponi L, Puglia D, Torre L, Valentini L, Kenny J. Processing of nanostructured polymers and advanced polymeric based nanocomposites. Mater Sci Eng R Rep. 2014;85:1-46.

64. Suchomel P, Kvitek L, Prucek R. Simple size-controlled synthesis of Au nanoparticles and their size-dependent catalytic activity. Sci Rep. 2018;8:4589.

65. Tsai H, Hu E, Perng K, Chen M, Wu JC, Chang YS. Instability of gold oxide Au2O3. Surf Sci. 2003;537:L447-50.

66. Jagadish K, Shiralgi Y, Chandrashekar BN, Dhananjaya BL, Srikantaswamy S. Ecofriendly synthesis of metal/metal oxide nanoparticles and their application in food packaging and food preservation. Impact Nanosci Food Indus. 2018;5:197-216.

67. Ahmad B, Hafeez N, Bashir S, Rauf A, Mujeeb-ur-Rehman, . Phytofabricated gold nanoparticles and their biomedical applications. Biomed Pharma. 2017;89:414-25.
68. Cui Y, Zhao Y, Tian Y, Zhang W, Lu X, Jiang X. The molecular mechanism of action of bactericidal gold nanoparticles on Escherichia coli. Biomaterials. 2012:33:2327-33.

69. Yu Z, Wang W, Kong F, Lin M, Mustapha A. Cellulose nanofibril/silver nanoparticle composite as an active food packaging system and its toxicity to human colon cells. Inter J Biol Macromol. 2019;129:887-94.

70. Kuswandi B. Moradi M Improvement of food packaging based on functional nanomaterial. Nanotechnology: applications in energy, drug and food. Cham: Springer; 2019. p. 309344.

71. Castro Mayorga JL, Fabra Rovira MJ, Cabedo Mas L, Sa'nchez Moragas G, Lagaro'n Cabello JM, . Antimicrobial nanocomposites and electrospun coatings based on poly(3-hydroxybutyrate- co-3-hydroxyvalerate) and copper oxide nanoparticles for active packaging and coating applications. J Appl Polym Sci. 2018;135:45673.

72. Almasi H, Jafarzadeh $P$, Mehryar L. Fabrication of novel nanohybrids by impregnation of CuO nanoparticles into bacterial cellulose and chitosan nanofibers: characterization, antimicrobial and release properties. Carbohydr Polym. 2018;186:273-81.

73. Muthulakshmi L, Varada Rajalu A, Kaliaraj GS, Siengchin S, Parameswaranpillai J, Saraswathi R. Preparation of cellulose/copper nanoparticles bionanocomposite films using a bioflocculant polymer as reducing agent for antibacterial and anticorrosion applications. Comp Part B: Eng. 2019;175:107-77.

74. Roy S, Rhim JW. Melanin-mediated synthesis of copper oxide nanoparticles and preparation of functional Agar/CuO np nanocomposite films. J Nanomat. 2019;2019:110.

75. Bodaghi H, Mostofi Y, Oromiehie A, Zamani Z, Ghanbarzadeh B, Costa C, Del Nobile MA. Evaluation of the photocatalytic antimicrobial effects of $\mathrm{a} \mathrm{TiO}_{2}$ nanocomposite food packaging film by in vitro and in vivo tests. LWT Food Sci Technol. 2013;50:702-6.

76. Tan R, Lv Z, Tang J, Wang Y, Guo J, Li L. Theoretical study of the adsorption characteristics and the environmental influence of ornidazole on the surface of photocatalyst $\mathrm{TiO}_{2}$. Sci Rep. 2019;9:10891.

77. Espitia PJP, Soares N, De FF, Coimbra JS, Dos R, De Andrade NJ, Medeiros EAA. Zinc oxide nanoparticles: synthesis, antimicrobial activity and food packaging applications. Food Bioproc Tech. 2012;5:1447-64.

78. Salah N, AL-Shawafi WM, Alshahrie A, Baghdadi N, Soliman YM, Memic A. Size controlled, antimicrobial ZnO nanostructures produced by the microwave assisted route. Mater Sci Eng C. 2019;99:1164-73.

79. Mirtalebi SS, Almasi H, Alizadeh Khaledabad M. Physical, morphological, antimicrobial and release properties of novel MgO-bacterial cellulose nanohybrids prepared by in-situ and ex-situ methods. Inter J Biol Macromol. 2019;128:848-57.

80. Swaroop C, Shukla M. Development of blown polylactic acid-MgO nanocomposite films for food packaging. Compos Part A Appl Sci Manuf. 2019;124:105482.

81. Azam A, Ahmed AS, Oves M, Khan MS, Habib SS, Memic A. Antimicrobial activity of metal oxide NPs against Gram positive and Gram-negative bacteria: a comparative study. Int J Nanomed. 2012;7:6003-9.

82. Shi LE, Li ZH, Zheng W, Zhao YF, Jin YF, Tang ZX. Synthesis, antibacterial activity, antibacterial mechanism and food applications of ZnO NPs: a review. Food Addit Conta, Part A Chem Anal Control Expo Risk Assess. 2014;31:173-86.

83. Akbar A, Anal AK. Zinc oxide NPs loaded active packaging, a challenge study against Salmonella typhimurium and Staphylococcus aureus in ready-to-eat poultry meat. Food Control. 2014;38:88-95.

84. Tankhiwale R, Bajpai SK. Preparation, characterization and antibacterial applications of ZnO-NPs coated polyethylene films for food packaging. Colloids Surf B Biointerfaces. 2012;90:16-20.

85. Chaudhary P, Fatima F, Kumar A. Relevance of nanomaterials in food packaging and its advanced future prospects. J Inorg Organomet Polym Mat. 2020;30:5180-92.

86. Bikiaris DN, Triantafyllidis KS. HDPE/Cu-nanofiber nanocomposites with enhanced antibacterial and oxygen barrier properties appropriate for food packaging applications. Mater Lett. 2013;93:1-4.

87. Zeng S, Baillargeat D, Ho HP, Yong KT. Nanomaterials enhanced surface plasmon resonance for biological and chemical sensing applications. Chem Soc Rev. 2014;43:3426-52.

88. Yang M, Kostov Y, Bruck HA, Rasooly A. Gold nanoparticle-based enhanced chemiluminescence immunosensor for detection of 
Staphylococcal Enterotoxin B (SEB) in food. Int J Food Microbiol. 2009;133:265271.

89. Bittar DB, Catelani TA, Nigoghossian K, Barud HDS, Ribeiro SJL, Pezza L, Pezza HR. Optimized synthesis of silver nanoparticles by factorial design with application for the determination of melamine in milk. Anal Lett. 2017;50:829841.

90. Kumar N, Seth R, Kumar H. Colorimetric detection of melamine in milk by citrate-stabilized gold nanoparticles. Anal Biochem. 2014:456:4349.

91. Li F, Li F, Yang G, Aguilar ZP, Lai W, Xu H. Asymmetric polymerase chain assay combined with propidium monoazide treatment and unmodified gold nanoparticles for colorimetric detection of viable emetic Bacillus cereus in milk. Sens Actuat B: Chem. 2018;255:1455-61.

92. Chen ZG, Zhong HX, Luo H, Zhang RY, Huang JR. Recombinase polymerase amplification combined with unmodified gold nanoparticles for salmonella detection in milk. Food Anal Meth. 2019;12:190197.

93. El-Nour AK, Eftaiha A, Al-Warthan A, Ammar R. Synthesis and applications of silver nanoparticles. Arab J Chem. 2010;3:135-40.

94. Caro C, Castillo PM, Klippstein R, Pozo D, Zaderenko AP Silver nanoparticles: Sensing and imaging applications. Silver Nanoparticles. 2010: 201-224

95. Madhavan AA, Qotainy R, Nair R (2019) Synthesis of functionalized silver nanoparticles and its application as chemical sensor. In Paper presented at the 2019 Advances in science and engineering technology international conferences (ASET)

96. Omole R, Torimiro N, Alayande S, Ajenifuja E. Silver nanoparticles synthesized from Bacillus subtilis for detection of deterioration in the post-harvest spoilage of fruit. Sustain Chem Pharm. 2018;10:3340.

97. Sachdev D, Kumar V, Maheshwari PH, Pasricha R, Baghel N. Silver based nanomaterial, as a selective colorimetric sensor for visual detection of post harvest spoilage in onion. Sens Actuators B Chem. 2016;228:471-9.

98. Devi R, Yadav S, Pundir CS. Amperometric determination of xanthine in fish meat by zinc oxide nanoparticle/chitosan/multiwalled carbon nanotube/polyaniline composite film bound xanthine oxidase. Analyst. 2012;137:754-9.

99. Joo J, Yim C, Kwon D, Lee J, Shin HH, Cha HJ, Jeon S. A facile and sensitive detection of pathogenic bacteria using magnetic nanoparticles and optical nanocrystal probes. Analyst. 2012;137:3609-12.

100. Albelda JA, Uzunoglu A, Santos GNC, Stanciu LA. Graphene-titanium dioxide nanocomposite based hypoxanthine sensor for assessment of meat freshness. Biosens Bioelectron. 2017:89:518-24.

101. Zhang M, An T, Hu X, Wang C, Sheng G, Fu J. Preparation and photocatalytic properties of a nanometer $\mathrm{ZnO}-\mathrm{SnO} 2$ coupled oxide. Appl Catal A Gen. 2004;260:215-22.

102. Sheikh A, Soni K, Lakshmi N. Study of $\mathrm{ZnO}-\mathrm{SnO} 2$ nanocomposites: Structural, topological and electrochemical properties. In AIP conference proceedings. AIP Publishing LLC; 2020. vol. 2220, No. 1, p. 020096).

103. Shim K, Kim J, Shahabuddin M, Yamauchi Y, Hossain MSA, Kim JH. Efficient wide range electrochemical bisphenol-A sensor by self-supported dendritic platinum nanoparticles on screenprinted carbon electrode. Sens Actuators B Chem. 2018;255:2800-8.

104. Pradhan N, Singh S, Ojha N, Shrivastava A, Barla A, Rai V, Bose S. Facets of nanotechnology as seen in food processing, packaging, and preservation industry. Bio Med res int. 2015;2015:1-17.

105. Ferńandez A, Soriano E, López-Carballo G, Picouet P, Lloret E, Gavara R, Hernândez-Mũnoz P. Preservation of aseptic conditions in absorbent pads by using silver nanotechnology. Food Res Int. 2009;42:1105-12.

106. Emamifar A, Kadivar M, Shahedi M, Soleimanian-Zad S. Effect of nanocomposite packaging containing $\mathrm{Ag}$ and $\mathrm{ZnO}$ on inactivation of Lactobacillus plantarum in orange juice. Food Contr. 2011;22:408-13.

107. Jin T, Gurtler J. Inactivation of Salmonella in liquid egg albumen by antimicrobial bottle coatings infused with allyl isothiocyanate, nisin and zinc oxide nanoparticles. J Appl Microbiol. 2011;110:704-12.

108. An J, Zhang M, Wang S, Tang J. Physical, chemical and microbiological changes in stored green asparagus spears as affected by coating of silver nanoparticles-PVP. LWT-Food Sci Technol. 2008;41:1100-7.

109. Wu M, Mei T, Lin C, Wang Y, Chen J, Le W, Chen B. Melanoma cell membrane biomimetic versatile CUS nanoprobes for homologous targeting photoacoustic imaging and photothermal chemotherapy. ACS Appl Mater Interfaces. 2020:12:16031-9.
110. Pirsa S, Shamusi TJMSE. Intelligent and active packaging of chicken thigh meat by conducting nano structure cellulose-polypyrrole-ZnO film. Mater Sci Eng C. 2019;102:798-809.

111. Kim I, Viswanathan K, Kasi G, Thanakkasaranee S, Sadeghi K, Seo J. ZnO nanostructures in active antibacterial food packaging: preparation methods, antimicrobial mechanisms, safety issues, future prospects, and challenges. Food Rev Int. 2020;5:1-29.

112. Krasniewska K, Galus S, Gniewosz M. Biopolymers-based materials containing silver nanoparticles as active packaging for food applications-a review. Int J Mol Sci. 2020;21:698.

113. Sun J, Jiang H, Wu H, Tong C, Pang J, Wu C. Multifunctional bionanocomposite films based on konjac glucomannan/chitosan with nano$\mathrm{ZnO}$ and mulberry anthocyanin extract for active food packaging. Food Hydrocoll. 2020;107:105942.

114. Bahrami A, Lipowsky R, Weikl T. Tubulation and aggregation of spherical nanoparticles adsorbed on vesicles. Phys Rev Letters. 2012;109:188102.

115. Ramji V, Vishnuvarthanan M. (2020) Influence of $\mathrm{NiO}$ supported silica nanoparticles on mechanical, barrier, optical and antibacterial properties of polylactic acid (PLA) bio nanocomposite films for food packaging applications. Silicon 1-8

116. Kim M, Jee SC, Shinde SK, Mistry BM, Saratale RG, Saratale GD, Ghodake GS, Kim DY, Sung JS, Kadam AA. Green-synthesis of anisotropic peptone-silver nanoparticles and its potential application as anti-bacterial agent. Polymers. 2019;11:271.

117. Pandey VK, Upadhyay SN, Niranjan K, Mishra PK. Antimicrobial biodegradable chitosan-based composite Nano-layers for food packaging. Int J Biol Macromol. 2020;157:212-9.

118. Prakash J, Vignesh K, Anusuya T, Kalaivani T, Ramachandran C, Sudha Rani R, Momna R, Imran K, Fazle E, Deog HO, DevanandVenkatasubbu GJ. Application of nanoparticles in food preservation and food processing. J Food Hyg Saf. 2019;34:317-24.

119. Munish G, Paramjeet S, Shveta R. Optimizing physical layer energy consumption for reliable communication in multi-hop wireless sensor networks. Ind J Sci Technol. 2015;8:1-7.

120. Primo JDO, Bittencourt C, Acosta S, Sierra-Castillo A, Colomer JF, Jaerger S, Teixeira VC, Anaissi FJ. Synthesis of zinc oxide nanoparticles by ecofriendly routes: adsorbent for copper removal from wastewater. Front Chem. 2020:8:571790.

121. Applerot G, Lellouche J, Lipovsky A, Nitzan Y, Lubart R, Gedanken A, Banin E. Understanding the antibacterial mechanism of CuO nanoparticles: revealing the route of induced oxidative stress. Small. 2012;8:3326-37.

122. Tamayo L, Azócar M, Kogan M, Riveros A, Páez M. Copperpolymer nanocomposites: an excellent and cost-effective biocide for use on antibacterial surfaces. Mater Sci Eng C Mater Biol Appl. 2016;69:1391-409.

123. Ibrahim K, Khalid S, Idrees K. Nanoparticles: Properties, applications and toxicities. Arab J Chem. 2019;12:908-31.

124. Ahmed J, Arfat YA, Bher A, Mulla M, Jacob H, Auras R. Active chicken meat packaging based on polylactide films and bimetallic Ag-Cu nanoparticles and essential oil. J Food Sci. 2018;83:1299-310.

125. Varaprasad K, Pariguana M, Raghavendra GM, Jayaramudu T, Sadiku ER. Development of biodegradable metaloxide/polymer nanocomposite

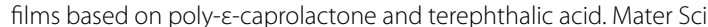
Eng C Mater Biol Appl. 2017;70:85-93.

126. Zhang W, Lu G, Li S, Liu Y, Xu H, Cui C, YanW YY, Huo F. Controlled incorporation of nanoparticles in metal-organic framework hybrid thin films. Chem Commun. 2014:50:4296-8.

127. Yaşa I, Lkhagvajav N, Koizhaiganova M, Celik E, Sarı O. Assessment of antimicrobial activity of nanosized $\mathrm{Ag}$ doped $\mathrm{TiO}(2)$ colloids. World $]$ Microbiol Biotechnol. 2012;28(7):2531-9.

128. Carolina ADS, Avinash PI, Mahendra R. The emerging role of metallic nanoparticles in food. Appl Microbiol Biotechnol. 2020;2:1-11.

129. Li Q, Mahendra S, Lyon DY, Brunet L, Liga MV, Li D. Antimicrobial nanomaterials for water disinfection and microbial control: potential applications and implications. Water Res. 2008:42:4591-602.

130. Kumar R, Munstedt $\mathrm{H}$. Silver ion release from antimicrobial polyamide/ silver composites. Biomaterials. 2005;26:2081-8.

131. Duncan TV. Applications of nanotechnology in food packaging and food safety: barrier materials, antimicrobials and sensors. J Colloid Interface Sci. 2011;363:1-24. 
132. Morones JR, Elechiguerra JL, Camacho A, Holt K, Kouri JB, Ramirez JT. The bactericidal effect of silver nanoparticles. Nanotechnol. 2005;16:2346-53.

133. Emamifar A, Kadivar M, Shahedi M, Soleimanian-Zad S. Evaluation of nanocomposites packaging containing $\mathrm{Ag}$ and $\mathrm{ZnO}$ on shelflife of fresh orange juice. Innov Food Sci Emerg Technol. 2011;11:742-8.

134. Cavaliere E, De Cesari S, Landini G, Riccobono E, Pallecchi L. Highly bactericidal Ag nanoparticle films obtained by cluster beam deposition. nanomedicine: nanotechnology. Biol Med. 2015;11:1417-23.

135. Rhim JW, Wang LF, Lee Y, Hong SI. Preparation and characterization of bio-nanocomposite films of agar and silver nanoparticles: laser ablation method. Carbohydr Polym. 2014;103:456-65.

136. Busolo MA, Fernandez P, Ocio MJ, Lagaron JM. Novel silverbased nanoclay as an antimicrobial in polylactic acid food packaging coatings. Food Addit Contam. 2010;27:1617-26.

137. Lin S, Chen L, Huang L, Cao S, Luo X, Liu K. Novel antimicrobial chitosan-cellulose composite films bioconjugated with silver nanoparticles. Ind Crops Prod. 2015;70:395-403.

138. Fayaz AM, Balaji K, Girilal M, Kalaichelvan PT, Venkatesan R. Mycobased synthesis of silver nanoparticles and their incorporation into Sodium Alginate films for vegetable and fruit preservation. J Agric Food Chem. 2009;57:6246-52.

139. Cobos M, De-La-Pinta I, Quindós G, Fernández MJ, Fernández MD. Graphene oxide-silver nanoparticle nanohybrids: synthesis, characterization, and antimicrobial properties. Nanomaterials. 2020;10:376.

140. Cioffi N, Torsi L, Ditaranto N, Tantillo G, Ghibelli L, Sabbatini L. Copper nanoparticle/polymer composites with antifungal and bacteriostatic properties. Chem Mater. 2005;17:5255-62.

141. Sheikh FA, Kanjawal MA, Saran S, Chung WJ, Kim H. Polyurethane nanofibers containing copper nanoparticles as future materials. Appl Surf Sci. 2011;257:3020-6.

142. Chatterjee AK, Chakraborty R, Basu T. Mechanism of antibacterial activity of copper nanoparticles. Nanotechnology. 2014;25:135101.

143. Vermeiren L, Devlieghere F, Debevere J. Effectiveness of some recent antimicrobial packaging concepts. Food Addit Contam. 2002;19:163-71.

144. Robertson JMC, Robertson PKJ, Lawton LA. A comparison of the effectiveness of $\mathrm{TiO}_{2}$ photocatalysis and UVA photolysis for the destruction of three pathogenic micro-organisms. J Photochem Photobiol. 2005;175:51-6.

145. Farhoodi M. Nanocomposite materials for food packaging applications: characterization and safety evaluation. Food Eng Rev. 2016;8:35-51.

146. Kubacka A, Diez MS, Rojo D, Bargiela R, Ciordia S, Zapico I. Understanding the antimicrobial mechanism of $\mathrm{TiO}_{2}$-based nanocomposite films in a pathogenic bacterium. Sci Rep. 2014;4:4134.

147. Cerrada ML, Serrano C, Sánchez-Chaves M, Fernández-García M, Fernández-Martín F, de Andrés A. Self-sterilized EVOHTiO, nanocomposites: effect of $\mathrm{TiO}_{2}$ content on biocidal properties. Adv Funct Mater. 2008;18:1949-60.

148. Maneerat $\mathrm{C}$, Hayata $\mathrm{Y}$. Antifungal activity of $\mathrm{TiO}_{2}$ photocatalysis against Penicillium expansum in vitro and in fruit tests. Int J Food Microbiol. 2006;107:99-103.

149. Yamamoto $\mathrm{O}$. Influence of particle size on the antibacterial activity of zinc oxide. Int J Inorg Mater. 2001;3:643-6.

150. Jones N, Ray B, Ranjit KT, Manna AC. Antibacterial activity of ZnO nanoparticle suspensions on a broad spectrum of microorganisms. FEMS Microbiol Lett. 2008:279:71-6.

151. Sirelkhatim A, Mahmud S, Seeni A, Kaus NHM, Ann LC, Bakhori SKM. Review on zinc oxide nanoparticles: antibacterial activity and toxicity mechanism. Nano-Micro Lett. 2015;7:219-42.

152. Youssef AM, El-Sayed SM, Salam HH, El-Sayed HS, Dufresne A. Evaluation of bionanocomposites as packaging material on properties of soft white cheese during storage period. Carboydr Polym. 2015;132:274-85.

153. Sharma C, Dhiman R, Rokana N, Panwar H. Nanotechnology: an untapped resource for food packaging. Front Microbiol. 2017:8:1735.

154. Dimitrijevica M, Karabasila N, Boskovica M, Teodorovica V, Vasileva D, Djordjevicb V. Safety aspects of nanotechnology applications in food packaging. Procedia Food Sci. 2015;5:57-60.

155. Huang JY, Li X, Zhou W. Safety assessment of nanocomposite for food packaging application. Trends Food Sci Technol. 2015;45:187-99.
156. Shang L, Nienhaus K, Nienhaus GU. Engineered nanoparticles interacting with cells: size matters. J Nanobiotechnol. 2014;12:1-11.

157. Youssef AM, Abdel-Aziz MS, El-Sayed SM. Chitosan nanocomposite films based on Ag-NP and Au-NP biosynthesis by Bacillus subtilis as packaging materials. Int J Biol Macromol. 2014;69:185-91.

158. Panea BG, Ripoll GJ, Fernández-Cuello A, Albert, í P, . Effect of nanocomposite packaging containing different proportions of $\mathrm{ZnO}$ and $\mathrm{Ag}$ on chicken breast meat quality. J Food Eng. 2013;123:104-12.

159. Zaman HU, Hun PD, Khan RA, Yoon KB. Morphology, mechanical, and crystallization behaviors of micro- and nano- ZnO filled polypropylene composites. J Reinf Plast Comp. 2012;31:323-9.

160. Emamhadi M, Sarafraz M, Akbari M, Thai V, Fakhri Y, Linh N, Mousavi K. Nanomaterials for food packaging applications: a systematic review. Food Chem Toxic. 2020;146:111825.

161. Jamshed M, Kumari S, Jinap S, Kamyar S, Sazili AQ. Reducing meat perishability through pullulan active packaging. J Food Qual. 2020. https:// doi.org/10.1155/2020/8880977.

162. Motelica L, Ficai D, Ficai A, Oprea OC, Kaya DA, Andronescu E. Biodegradable antimicrobial food packaging: trends and perspectives. Foods. 2020:9:1438.

163. Kraśniewska K, Galus S, Gniewosz M. Biopolymers-based materials containing silver nanoparticles as active packaging for food applications-a review. Int J Mol Sci. 2020;21:698.

164. Zhang H, Hortal M, Jordá-Beneyto M, Rosa E, Lara-Lledo M, Lorente I. ZnO-PLA nanocomposite coated paper for antimicrobial packaging application. LWT Food Sci Tech. 2017;78:250-7.

165. Kumar S, Mukherjee A, Dutta J. Chitosan based nanocomposite films and coatings: emerging antimicrobial food packaging alternatives. Trends Food Sci Technol. 2020:97:196-209.

166. Lavinia M, Hibaturrahman SN, Harinata H, Wardana AA. Antimicrobial activity and application of nanocomposite coating from chitosan and ZnO nanoparticle to inhibit microbial growth on fresh-cut papaya. Food Res. 2019;4:307-11.

167. Ewelina J, Pavel K, Lesław J, Agnieszka K, Zuzana B, Vedran M, Małgorzata M. Development of furcellaran-gelatin films with Se-AgNPs as an active packaging system for extension of mini kiwi shelf life. Food Packaging Shelf Life. 2019;21:100339.

168. Huang Y, Mei L, Chen X, Wang Q. Recent developments in food packaging based on nanomaterials. Nanomaterials. 2018;8:830.

169. Diogo VQ, Olga M, Gemma M. Recent advances in polymer-metallic composites for food packaging applications. Trends Food Sci Technol. 2021;109:230-44

170. Panea B, Albertí P, Ripoll G. Effect of high pressure, Calcium Chloride and $\mathrm{ZnO}-\mathrm{Ag}$ nanoparticles on beef color and shear stress. Foods. 2020;9:179.

171. Shimoga G, Shin EJ, Kim SY. Silver nanoparticles incorporated PVC films: evaluation of structural, thermal, dielectric and catalytic properties. Polímeros. 2019;29:e2019032.

172. Rong G, Hui Y, Lifei C, Qian W, Xiujie H. Regenerated cellulose films with amino-terminated hyperbranched polyamic anchored nanosilver for active food packaging. ACS Appl Bio Mater. 2020;3:602-10.

173. Mathew S, Nil J, Babu S. Biodegradable and active nanocomposite pouches reinforced with silver nanoparticles for improved packaging of chicken sausages. Food Packaging Shelf Life. 2019;19:155-66.

174. Biswas MC, Tiimob BJ, Abdela W, Jeelani S, Rangari VK. Nano silicacarbon-silver ternary hybrid induced antimicrobial composite films for food packaging application. Food Packaging Shelf Life. 2019;19:104-13.

175. Natsir M, Wati I, Ode L, Salim A, Mustapa F, Maulidiyah M, Azis T, Mahmud A, Muzakkar M, Nurdin M. Application of $\mathrm{TiO}_{2}-\mathrm{S}$ modified clay composite for adsorption-degradation of methylene blue. Tech Rep Kansai Univ. 2020;6:4539-50.

176. Brito SDC, Bresolin JD, Sivieri K, Ferreira MD. Low-density polyethylene films incorporated with silver nanoparticles to promote antimicrobial efficiency in food packaging. Food Sci Technol Int. 2020;26:353-66.

177. Ghasemi VM, Mohammad RA, Yoosefian SH, Izadi Z. Effects of the combination of gamma irradiation and Ag nanoparticles polyethylene films on the quality of fresh bottom mushroom (Agaricus bisporus L.). J Food Process Preserv. 2018:42:e13652.

178. Azlin HS, Cruz RMC, Morris MA, Cummins E, Kerry JP. Spray coating application for the development of nanocoated antimicrobia 
low-density polyethylene films to increase the shelf life of chicken breast fillets. Food Sci Technol Int. 2018;24:688-98.

179. Gupta A, Sophie MB, Sam S, Hazel G, Vinodh K, Grazyna A, Marek K, Claire M, Iza R. Synthesis of silver nanoparticles using curcumin-cyclodextrins loaded into bacterial cellulose-based hydrogels for wound dressing applications. Biomacromol. 2020;21:1802-11.

180. Ramachandraiah K, Gnoc N, Chin K. Biosynthesis of silver nanoparticles from persimmon by products and incorporation in biodegradable sodium alginate thin film. J Food Sci. 2017;82:2329-36.

181. Xing Y, Li W, Wang Q, Li X, Xu Q, Guo X, Bi X, Liu X, Shui Y, Lin H, Yang H. Antimicrobial nanoparticles incorporated in edible coatings and films for the preservation of fruits and vegetables. Molecules. 2019;24:1695.

182. Zhengguo W, Wei Z, Chunsheng P, Weijie D, Changliang X, Xiaoying W. Multifunctional chitosan-based coating with liposomes containing laurel essential oils and nanosilver for pork preservation. Food Chem. 2019;295:16-25.

183. Hai C, Shixu S, Man L, Cheng Z, Wenhui L, Lin L, Yuyue Q. Effect of PLA nanocomposite films containing bergamot essential oil, $\mathrm{TiO}_{2}$ nanoparticles, and Ag nanoparticles on shelf life of mangoes. Sci Horti. 2019:249:192-8

184. Wu Z, Huang X, Li YC, Xiao H, Wang X. Novel chitosan films with laponite immobilized Ag nanoparticles for active food packaging. Carbohydr Polym. 2018;199:210-8.

185. Raquel B, Cristina N, Filomena S. Encapsulation systems for antimicrobial food packaging components: an update. Molecules. 2020;25:1134.

186. Simbine EO, Rodrigues LDC, Lapa-Guimarães JK, Eliana S, Corassin CH, Oliveira CAF. Application of silver nanoparticles in food packages: a review. Food Sci Technol. 2019;39:793-802.

187. Lin QB, Li H, Zhong HN, Zhao Q, Xiao DH, Wang ZW. Migration of Ti from nano- $\mathrm{TiO}_{2}$ - polyethylene composite packaging into food simulants. Food Addit Contam Part A. 2014:31:1284-90.

188. Lian Z, Zhang Y, Zhao Y. Nano-TiO ${ }_{2}$ particles and high hydrostatic pressure treatment for improving functionality of polyvinyl alcohol and chitosan composite films and nano- $\mathrm{TiO}_{2}$ migration from film matrix in food simulants. Innov Food Sci Emerg Technol. 2016;33:145-53.

189. Li W, Li L, Zhang H, Yuan M, Qin Y. Evaluation of PLA nanocomposite films on physicochemical and microbiological properties of refrigerated cottage cheese. J Food Process Preserv. 2018;42:e13362.

190. Li W, Zhang C, Chi H, Li L, Lan T, Han P, Chen H, Qin Y. Development of antimicrobial packaging film made from poly (lactic acid) incorporating titanium dioxide and silver nanoparticles. Molecules. 2017;22:1170.

191. Emamifar A, Kadivar M, Shahedi M, Soleimanian-Zad S. Effect of nanocomposite packaging containing $\mathrm{Ag}$ and $\mathrm{ZnO}$ on inactivation of Lactobacillus plantarum in orange juice. Food Control. 2011;22:408-13.

192. Panea B, Ripoll G, González J, Fernández-Cuello Á, Albertí P. Effect of nanocomposite packaging containing different proportions of $\mathrm{ZnO}$ and Ag on chicken breast meat quality. J Food Eng. 2014;123:104-12.

193. Beigmohammadi F, Peighambardoust SH, Hesari J, Azadmard-Damirchi S, Peighambardoust SJ, Khosrowshahi NK. Antibacterial properties of LDPE nanocomposite films in packaging of UF cheese. LWT Food Sci Technol. 2016;65:106-11.

194. Vähä-Nissi M, Pitkänen M, Salo E, Sievänen-Rahijärvi J, Putkonen M, Harlin A. Atomic layer deposited thin barrier films for packaging. Cellul Chem Technol. 2015;49:575-85.

195. Donglu F, Wenjian Y, Kimatu BM, Mariga AM, Liyan Z, Xinxin A, Qiuhui $H$. Effect of nanocomposite-based packaging on storage stability of mushrooms (Flammulina velutipes). Innov Food Sci Emerg Technol. 2016;33:489-97.

196. Badawy MEI, Lotfy TMR, Shawir SMS. Preparation and antibacterial activity of chitosan-silver nanoparticles for application in preservation of minced meat. Bull Natl Res Cent. 2019;43:83.

197. Kargozari M, Hamedi H. Incorporation of essential oils (EOs) and nanoparticles (NPs) into active packaging systems in meat and meat products: a review. Food Health. 2019;2:16-30.

198. Pirsa S, Abdolsattari P, Peighambardoust SJ, Fasihnia SH, Peighambardoust SH. Investigating microbial properties of traditional Iranian white cheese packed in active LDPE films incorporating metallic and organoclay nanoparticles. Chem Rev Lett. 2020;3:168-74.

199. Amanulla F, Kuzhandhaivelu B, Girilal M, Puthupalayam TK, Ramasamy $\checkmark$. Mycobased synthesis of silver nanoparticles and their incorporation into sodium alginate films for vegetable and fruit preservation. J Agric Food Chem. 2009;57:6246-52.

200. Liao C, Li Y, Tjong SC. Bactericidal and cytotoxic properties of silver nanoparticles. Int J Mol Sci. 2019;20:449.

201. Booren BL, Castell-Perez ME, Miller RK. Effect of meat enhancement solutions with hydroxypropyl methylcellulose and konjac flour on texture and quality attributes of pale, soft, and exudative pork. J Texture Stud. 2017:48:403-14.

202. Colin C, Vicente-Ramírez E, Soto-Valdez H, Peralta E, Auras R. The release of carotenoids from a light-protected antioxidant active packaging designed to improve the stability of soybean oil. Food Bioproc Tech. 2014;7:3504-15.

203. Feng Z, Li L, Wang Q, Wu G, Liu C, Jiang B, Xu J. Effect of antioxidant and antimicrobial coating based on whey protein nanofibrils with $\mathrm{TiO}_{2}$ nanotubes on the quality and shelf life of chilled meat. Int J Mol Sci. 2019:20:1184

204. Gumiero M, Peressini D, Pizzariello A, Sensidoni A, lacumin L, Comi G, Toniolo R. Effect of $\mathrm{TiO}_{2}$ photocatalytic activity in HDPE-based food packaging on the structural and microbiological stability of a shortripened cheese. Food Chem. 2013;138:1633-40.

205. Tran M, Rad M, Alavi M. Antibacterial activity of copper oxide (CuO) nanoparticles biosynthesized by bacillus sp. fu4: optimization of experiment design. Pharma Sci. 2017:23:198-206.

206. Viktoriia H, Maksym P, Korniienko V, Kalinkevych O, Ivashchenko O, Peplińska B, Jarek M (2017) Antibacterial activity of the new copper nanoparticles and Cu NPs/chitosan solution. 04NB10-1

207. Qing Y, Cheng L, Li R, Liu G, Zhang Y, Tang X, Wang J, Liu H, Qin Y. Potential antibacterial mechanism of silver nanoparticles and the optimization of orthopedic implants by advanced modification technologies. Int J Nanomed. 2018;13:3311-27.

208. Abebe B, Zereffa EA, Tadesse A. A review on enhancing the antibacterial activity of $\mathrm{ZnO}$ : mechanisms and microscopic investigation. Nanoscale Res Lett. 2020;15:190.

209. Tang ZX, Lv BF. MgO nanoparticles as antibacterial agent: preparation and activity. Braz J Chem Eng. 2014;31:591-601.

210. Wang L, Hu C, Shao L. The antimicrobial activity of nanoparticles: present situation and prospects for the future. Int I Nanomed. 2017:12:1227-49.

211. Azizi-Lalabadi M, Ehsani A, Divband B. Antimicrobial activity of titanium dioxide and zinc oxide nanoparticles supported in 4a zeolite and evaluation the morphological characteristic. Sci Rep. 2019;9:17439.

212. Salvadori M, Monezi T, Mehnert D, Corrêa B. Antimicrobial activity of ag/ag2o nanoparticles synthesized by dead biomass of yeast and their biocompatibility with mammalian cell lines. Inter J Res Stud Microbiol Biotech. 2019:5:2454-9428.

213. Britto HR, Cortez-Valadez M, Flores-Lopez NS. Agglomerates of Au-Pt bimetallic nanoparticles: synthesis and antibacterial activity. Gold Bull. 2020;53:93-100

214. Mohamed M, Ahmed K, Nazeer K, Prem N, Kumar D, Thamilselvan M. Synthesis, characterization and magnetic properties of hematite (a-Fe2O3) nanoparticles on polysaccharide templates and their antibacterial activity. Appl Nanosci. 2014;5:515-20.

215. Bartyzel A, Głuchowska H. Influence of temperature on the crystallization of Cull complex with tetradentate Schiff base. J Coord Chem. 2016;69:3206-18.

216. Tang S, Zheng J. Antibacterial activity of silver nanoparticles: structural effects. Adv Health Mater. 2018;7:e1701503.

\section{Publisher's Note}

Springer Nature remains neutral with regard to jurisdictional claims in published maps and institutional affiliations. 